University of Louisville ThinkIR: The University of Louisville's Institutional Repository

Electronic Theses and Dissertations

$5-2019$

\title{
Schumpeter revisited : faster better cheaper as grounds for entrepreneurial success and a path to an IPO.
}

Charles Raymond Olsavsky

University of Louisville

Follow this and additional works at: https://ir.library.louisville.edu/etd

Part of the Entrepreneurial and Small Business Operations Commons

\section{Recommended Citation}

Olsavsky, Charles Raymond, "Schumpeter revisited : faster better cheaper as grounds for entrepreneurial success and a path to an IPO." (2019). Electronic Theses and Dissertations. Paper 3183.

https://doi.org/10.18297/etd/3183

This Doctoral Dissertation is brought to you for free and open access by ThinkIR: The University of Louisville's Institutional Repository. It has been accepted for inclusion in Electronic Theses and Dissertations by an authorized administrator of ThinkIR: The University of Louisville's Institutional Repository. This title appears here courtesy of the author, who has retained all other copyrights. For more information, please contact thinkir@louisville.edu. 


\title{
SCHUMPETER REVISITED: FASTER BETTER CHEAPER AS GROUNDS FOR ENTREPRENEURIAL SUCCESS AND A PATH TO AN IPO
}

\section{By}

\section{Charles Raymond Olsavsky}

B.E., Youngstown State University, 1979

J.D., University of Akron, 1987

M.B.A., University of Michigan (Ann Arbor), 2012

\author{
A Dissertation \\ Submitted to the Faculty of the \\ College of Business of the University of Louisville \\ in Partial Fulfillment of the Requirements \\ for the Degree of \\ Doctor of Philosophy \\ in Entrepreneurship \\ Entrepreneurship Department \\ College of Business \\ University of Louisville \\ Louisville, Kentucky
}

May 2019 
Copyright 2019 by Charles Raymond Olsavsky

All rights reserved 



\title{
SCHUMPETER REVISITED: FASTER BETTER CHEAPER AS GROUNDS FOR \\ ENTREPRENEURIAL SUCCESS AND A PATH TO AN IPO
}

\author{
By \\ Charles Raymond Olsavsky \\ B.E., Youngstown State University, 1979 \\ J.D., University of Akron, 1987 \\ M.B.A., University of Michigan (Ann Arbor), 2012 \\ A Dissertation Approved on
}

April 15 th 2019

by the following Dissertation Committee:

Dr. James O. Fiet

Dr. Robert P. Garrett

Dr. Andrew Manikas

Dr. Jeff Guan 


\section{DEDICATION}

This dissertation is dedicated to my family including

my wife Linda Olsavsky

and our kids

Bethann Olsavsky

Chas Olsavsky

Amber Parker

and

Stephanie Blubaugh

for their support through a difficult time. 


\section{ACKNOWLEDGEMENTS}

I would like to thank my wife Linda Olsavsky for all of her patience, hard work and support. Due to my handicaps and her IT skills, she provided help and support that was much greater than the usual support of a spouse.

I would like to thank my dissertation chair, Dr. Fiet for his hard work, patience and valuable guidance through the dissertation process. I would also like to thank my other committee members for assistance and comments: Dr. Garrett, especially for his comments on producing publishable articles; Dr. Manikas, especially for his guidance on Dr. Hammer research; and Dr. Juan, especially for his guidance on research methodology.

I would also like to thank Dr. Kenney and Dr. Martin (both at UC Davis) for giving me access to their database Firm Database of Emerging Growth Initial Public Offerings (IPOs) from 1990 through 2015. I could not have completed the dissertation without the database. 


\title{
ABSTRACT \\ SCHUMPETER REVISITED: FASTER BETTER CHEAPER AS GROUNDS FOR ENTREPRENEURIAL SUCCESS AND A PATH TO AN IPO
}

\author{
By \\ Charles Raymond Olsavsky
}

April 15, 2019

Current entrepreneurship research focuses on two types of entrepreneurial firms: (1) the firms that develop innovative novel products or services arising from technological innovation; and (2) the firms that develop innovative novel products or services arising from recognition of an opportunity in existing conditions, no type of change required. A third type of business founder has been largely ignored in the modern entrepreneurship research - - the founder who enters a competitive market with no novel product or service that he or she invented. I refer to this founder in a competitive market as a performance entrepreneur. This dissertation presents theory to argue that there are high growth opportunities in certain competitive markets and analyzes the prevalence of performance entrepreneurs among US IPO firms. Of particular interest is the performance entrepreneur who enters a new competitive market recently enabled by new technology.

I present theoretical arguments (under a resource based view(RBV)) that the majority of high growth firms are performance entrepreneurship firms, not firms with innovative new products. Joseph Schumpeter opined in 1942 that technological advances were becoming too complex for entrepreneurial firms. Michael Hammer opined through 
the 1990s and early 2000's that many business opportunities would arise through efficiency as a result of technological changes. I utilize these opinions and theories to advance my theory.

In a stratified research effort, I reviewed SEC filings of over 500 firms that went through IPOs in the 1995-2015 period. IPO firms are firms very successful firms that have achieved high growth and are generally considered to be at the pinnacle of entrepreneurship. My interest is the business ventures pursued by successful firms.

The research showed that over $80 \%$ of these firms were performance entrepreneurship firms, not firms that had developed high technology products or services. This research is important because it shines a light on an important group of entrepreneurs who have been largely ignored in the modern entrepreneurship, even though they figured prominently in the traditional entrepreneurship. 
TABLE OF CONTENTS

PAGE

ACKNOWLEDGMENTS .................................................................................iv

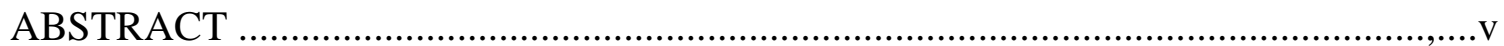

LIST OF TABLES .................................................................................. viii

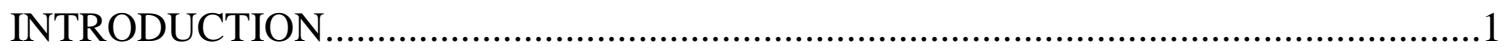

LITERATURE REVIEW AND HYPOTHESIS EVELOPMENT ...............................11

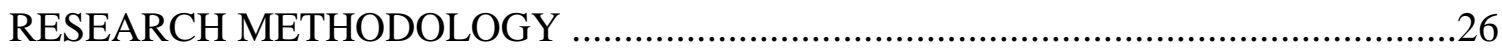

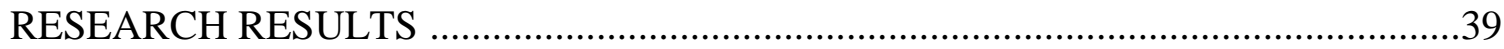

DISCUSSION AND CONCLUSIONS .............................................................. 47

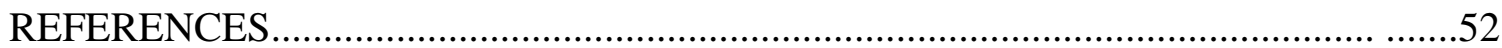

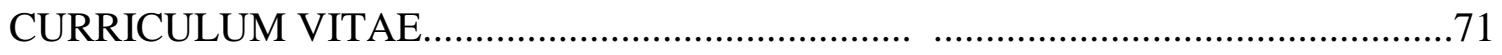




\section{LIST OF TABLES}

TABLE

PAGE

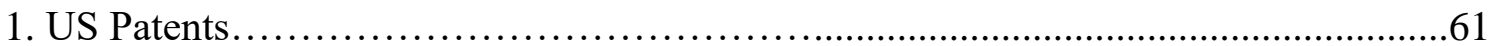

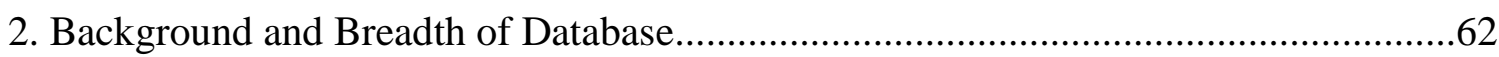

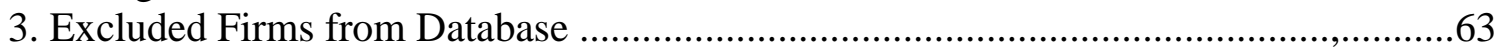

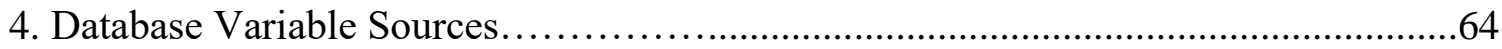

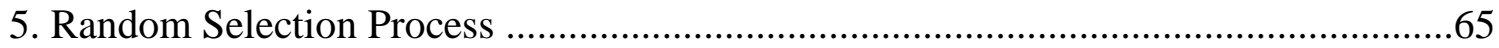

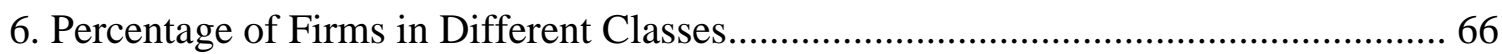

7. Percentage of Tech-Maker Confidence Levels....................................................67

8. Test Comparing Tech-Maker and Performance Entrepreneurship................................68

9. Test Comparing Kirznerian and Performance Entrepreneurship.................................69

10. Test Comparing Tech-Maker and T. Enabled Performance Entrepreneurship............70 


\section{CHAPTER I}

\section{INTRODUCTION}

\section{Current Theory That We Know}

There is an emphasis in the modern entrepreneurship research on business founders who have a novel product or service. In the last 15 years, a debate of entrepreneurship researchers has been whether entrepreneurs "discover" opportunities to start businesses or whether entrepreneurs "create" opportunities to start businesses (Alvarez et al., 2013; Alvarez \& Barney, 2007). The discover or create debate centers on business founders with novel products or services.

Concerning the creation process, Alvarez and Barney (2007, p. 15) describe entrepreneurial opportunities as "created, endogenously, by the actions, reactions, and enactments of entrepreneurs exploring ways to produce new products or services (Baker and Nelson, 2005; Gartner, 1985; Sarasvathy, 2001; Weick, 1979)."

Turning to discovery, the discovery process generally involves entrepreneurs who are able to see new opportunities in the markets that nonentrepreneurs cannot see (Alvarez \& Barney, 2007; Kirzner, 1973). Kirzner refers to the skill to see new opportunities as "alertness" (Kirzner, 1973, p. 6). The concept of alertness really does not apply to a business founder entering a competitive market that many see the opportunity for, especially if her or his plan is simply to perform better than the competition. Thus, (1) the creation view expressly requires a novel product or service and (2) the discovery view requires a novel product or service, or some other novelty that was discovered by alertness. 
In an article published in a leading management journal for theoretical research, the Academy of Management Review (AMR), Ramoglou and Tsang (2016) propose that the discover/create debate can be solved by referring to entrepreneurial efforts as actualization rather than discovery or creation. In doing so, they clarify the requirement of a new product or service in order for activity to be entrepreneurial. Ramoglou and Tsang (2016, p. 411) define entrepreneurial opportunity as "the propensity of market demand to be actualized into profits through the introduction of novel products or services." Thus, once again a novel product or service is required in a modern definition concerning entrepreneurship.

Ramoglou and Tsang (2016) note that "entrepreneurship" can include introducing a product that is novel to one market, but not novel globally. However, they point out that their definition of entrepreneurship does not include typical innovative efforts in a competitive environment such as innovative cost-cutting. They state that under their definition of entrepreneurship, all innovation is not entrepreneurial, only innovation that produces novel products or services.

Various leading scholars have responded to the Ramoglou and Tsang (2016) article in the Dialogue section of AMR. Further, Davidsson (2017) responded with an article in Journal of Business Venturing Insights. All of the critique of the Ramoglou and Tsang (2016) article concerns philosophical points, not an objection to the requirement for novel products or services. Consequently, much of the entrepreneurship research community apparently concurs with the concept that entrepreneurship requires a novel products or service.

Looking at entrepreneurship through another lense, often entrepreneurship researchers put entrepreneurship into two categories: (1) Schumpeterian; and (2) 
Kirznerian (Foss \& Klein, 2010; Shane, 2003). The term Schumpeterian entrepreneurship is named after the economist Joseph Schumpeter and refers to entrepreneurship that arises out of some type of change, usually technological but possibly political, economic, or social change (Schumpeter, 1934; Shane, 2003). A classic example of Schumpeterian entrepreneurship is an entrepreneurial pharmaceutical firm inventing and commercializing a new breakthrough drug.

The term Kirznerian entrepreneurship is named after the Austrian economist Israel Kirzner and refers to entrepreneurship concerning alertness to arbitrage type opportunities- no technological or societal change required (Shane, 2003). Under the Kirznerian definition, entrepreneurship is the act of discovering, or being alert to, opportunities that others fail to realize. It often contains an element of surprise (Kirzner, 1997). The discovery entails discovering an opportunity that was right under the nose of everybody, but everybody failed to recognize before now (Kirzner, 1997). A classic example of Kirznerian entrepreneurship is an entrepreneur inventing a simple new product that leaves many kicking themselves, saying "why didn't I think of that".

The Kirznerian notion of entrepreneurship as defined by modern scholars does not absolutely have a strict requirement of a novel product or service like the modern concepts of creation and actualization, but it certainly includes and anticipates ventures with creative new products (cf. Foss \& Klein, 2010; Shane, 2003). Similarly, while Schumpeterian entrepreneurship as defined by modern scholars arguably could include a venture with a launch other than a launch with a technologically innovative new product, the innovative new product launch is certainly a focus of the modern Schumpeterian entrepreneurship definition (cf. Foss \& Klein, 2010; Shane, 2003). 
Arguably, the emphasis on novel products and services in the literature is justifiable by theory. Alvarez and Barney (2007, p.14) cite Barney (1986) in opining theory that "In a setting where everyone could potentially become aware of and exploit an opportunity, it would be difficult for anyone to generate sufficient profits from actually producing new products or services." In other words, it is difficult to make money in a competitive market. This difficulty in a competitive market arguably makes founders of businesses in competitive markets less interesting than founders with novel products or services.

\section{$\underline{\text { Research Results That We Know }}$}

With the emphasis on firms launched with novel products and services, a critical event of entrepreneurship is discovering a novel product or service. Also, a critical point in time is when the discovery is made. In the modern entrepreneurship literature, entrepreneurship has been defined as the discovery, evaluation and exploitation of

opportunities to introduce future goods and services (Venkataraman, 1997). This definition highlights the importance of the discovery of a novel product or service because exploitation (benefitting from) follows their discovery.

Following this logic, there has been extensive research concerning the characteristics of the persons who launch these firms with novel products or services. There has been over two decades of research concerning the differences between these entrepreneurs and nonentrepreneurs (Alvarez \&Barney, 2007; Busenitz \& Barney, 1997).

\section{What We Do Not Know}

In the modern entrepreneurship literature, regardless of whether one is talking about discovering, creating, actualizing, Schumpeterian or Kirznerian, there are two basic themes 
to the literature: (1) a new product or service and (2) avoiding competition. Kirznerian entrepreneurs avoid competition via arbitrage conditions. The usual Schumpeterian entrepreneurs avoid competition via technological innovation. The competition avoidance meshes well with the theory of both (1) Alvarez \& Barney (2007) and (2) Barney (1986) that it is hard to make money on a venture when many can see the venture opportunity.

Certainly, it is advisable to avoid competition when possible. However, it is not always possible to avoid competition. I argue that it is difficult, if not nearly impossible to do so in most situations. Usually, it is necessary to face competition if you want to start a firm. There has not been extensive research in the modern entrepreneurship literature concerning business founders who enter competitive markets with no novel product or service.

Theory says that entrepreneurial opportunities arise from change such as technological, political, cultural, legal and social change (Schumpeter, 1934). Yet, there has not been extensive research concerning business founders utilizing recently developed technology to develop ventures dependent on the new technology in a competitive environment.

It is common knowledge that most business startups fail. Although there has been extensive research into the distinctions between entrepreneurs and nonentrepreneurs, there has not been research into the distinctions between successful entrepreneurs and failed entrepreneurs.

Important issues in resource-based (RBV) theory are how entrepreneurs source heterogeneous and hard to copy resources and capabilities to develop sustained competitive advantage (Barney, 1991). There has not been extensive research into the sourcing of 
heterogeneous resources needed by business founders in competitive markets to attain sustainable competitive advantage (cf. Barney, 1991).

Entrepreneurship literature focuses on innovation to develop new products to avoid competition. However, there are other types of innovation. Byers, Dorf and Nelson (2010) define radical innovation or disruptive innovation as creating new products or services - what the entrepreneurship research has covered. They define incremental innovation as characterized by faster better or cheaper versions of existing products or services, either an improved version of the product or service, better delivery of the same product or service, or offering the same product or service at a better price. The business founder in a competitive environment performs incremental innovation and this type of innovation has not been covered extensively in the entrepreneurship literature.

\section{$\underline{\text { Research Question }}$}

I define one term to set up my research question. The startup firm entering a competitive market competing on incremental innovation does not fit well into either the Schumpeterian or Kirznerian category. I argue it is really a third type of entrepreneurial firm. This firm really does not create, discover or actualize anything because it does not have the "novel" product or service contemplated in the literature. It does not benefit from being alert to opportunities that others did not see, and it does not have a technologically innovative new product.

I realize that this type of business founder is outside the scope of some researchers' definition of entrepreneurship. Arguably, depending how broadly Schumpeterian and Kirznerian entrepreneurship is defined, this firm could fit under one of those definitions. However, under the recent AMJ Ramoglou and Tsang view, the firm falls completely outside the definition of entrepreneurship. 
I refer to this type of a business founder as a performance entrepreneur. The performance entrepreneur really does not discover an opportunity or anything at all because he or she is either: (A) pursuing the same opportunity that (1) the incumbent competition is already pursuing while operating in plain sight and/or (2) other entrepreneurs are planning to pursue; or (B) attempting to sell a product or service invented by a third party. Further, the performance entrepreneur really does not exploit any opportunity, but rather he or she (1) competes for market space in a competitive environment or (2) attempts to market a new product or service developed by a third party.

In this dissertation, I investigate how prevalent performance entrepreneurship firms are in the ranks of US IPO firms that (1) have not created or developed new products, but (2) do have a business model that depends on technology recently developed by others. An example of this could be an entrepreneurial retail firm formed to compete in a soon to be crowded market selling and installing new technologically innovative products developed and manufactured by a third party. Specifically, my main research question is:

In the ranks of US IPO firms, how prevalent are performance entrepreneurship firms that have a business model that depends on new technology recently developed by others?

Recent entrepreneurship research has focused on innovative new products and services as the key to entrepreneurial success. The business founder who enters a competitive market is viewed as less attractive, almost certainly not a good enough candidate to achieve the pinnacle. I question and investigate that thinking. While classic economics says that competitive markets do not have high profit potential, I investigate 
how often performance entrepreneurs break through barriers and achieve extraordinary profits in competitive environments.

Few would doubt that there are numerous performance entrepreneurship opportunities that are not high growth opportunities such as local house painting, bakeries, handyman services, car washes and lawn services. This is obvious and beyond dispute. By looking at IPO firms, I investigate (1) whether it is really necessary to have an innovative novel offering to reach the pinnacle of entrepreneurship, an IPO (Shane, 2003), or (2) whether performance entrepreneurs often reach this pinnacle.

\section{$\underline{\text { Traditional Research }}$}

While the performance entrepreneur may have been neglected in modern research, the performance entrepreneur is present in the traditional research. This emphasis in the modern literature for a novel product or service is a departure from early entrepreneurship research, including Schumpeter's thinking. Schumpeter had a broad definition of entrepreneurship that did not require a novel product or service. His definition of entrepreneurship included not only introducing new products, but also new production methods, new sources of supply and new industrial combinations (Schumpeter, 1934, 1939, 1942). Thus, while new innovative production methods to reduce costs is not entrepreneurial under Ramoglou and Tsang's definition, they are under Schumpeter's definition of entrepreneurship. Apparently, modern researchers have narrowed the scope of entrepreneurship.

The modern narrowing of the study of entrepreneurship is not only inconsistent with Schumpeter, but other early entrepreneurship scholars as well. For instance, Cantillion (1755) viewed the entrepreneur as a person motivated by profit to engage in 
arbitrage by buying at a certain price and selling at an uncertain price. Later, Menger (1871) viewed the entrepreneur as a capitalist and manager who: (1) assesses the economic landscape; (2) makes economic calculations and predictions about potential business activity; (3) willfully sets planned business activity into motion; and (4) supervises the business activity.

Mises (1949) viewed the entrepreneur as a speculator attempting to make a profit off his/her opinions about future economic circumstances. None of these scholars require entrepreneurship to involve a novel product or service. Even more recently, Shane (2003) had a definition of entrepreneurship that did not require a new product or service offering by the entrepreneurial firm.

\section{$\underline{\text { Research Question Importance }}$}

This is an important issue. In order for the field of entrepreneurship to advance, empirical research concerning entrepreneur activity in discovering/selecting ventures is needed (Shane, 2016). This study is such research. Moreover, the prevalence of the performance entrepreneur may shine a light on an important entrepreneur who has been ignored in the modern entrepreneurship research.

Performance entrepreneurship may be more profitable than theorized. Performance entrepreneurs may be more prevalent among the ranks of highly successful entrepreneurs than expected. The performance entrepreneur, although neglected in most modern research, is part of the entrepreneurship family in the traditional literature. These are important areas of research that are currently not researched. 
The field of entrepreneurship cannot advance until an understanding is developed of what entrepreneurs actually do (Aldrich \& Ruef, 2019). This dissertation performs important work towards that mission.

\section{Examples of Performance Entrepreneurship}

I want to point out some examples of highly successful performance entrepreneurs to help motivate interest in the study of performance entrepreneurs. These entrepreneurs did not have innovative novel products or services when they started, but instead mostly (1) competed on price or (2) competed with an arguably better version of an existing product already on the market.

Sam Walton built his Walmart empire without any innovative, clever new products dreamed up in a Kirznerian moment of brilliance. He sold his products through the same basic channels (brick and mortar stores) as the competition and sold the exact same toothpaste, laundry detergent and paper towels as the competition. The Amazon history is similar, it started out selling the exact same music, books and videos as the competition in a new method (e commerce) that was being attempted by many.

Apple did not invent the PC. Instead, it came out with an improved version of the PC which sold well. There were multiple PCs on the market before Apple appeared. Microsoft's early history is similar - - not innovative new and different products, but better versions of existing products.

Google did not invent the search engine. Twelve other firms had search engines up and running before Google. VC firms passed on investing in Google because Google was a late comer entering an already crowded market with more competition yet entering. Google succeeded because it had a better version of an already existing service. 
Facebook's history parallels Google's. Facebook did not invent social media. When Facebook started, My Space had a dominant market share which Facebook had to overcome. Certainly, these are cherry picked examples of firms. This dissertation will explore if they are outliers, or if they are mainstream in the ranks of IPO firms. 
CHAPTER II

\section{LITERATURE REVIEW AND HYPOTHESES DEVELOPMENT}

\section{$\underline{\text { Definitions }}$}

To streamline the rest of the dissertation, I introduce three more definitions. I assign two classifications to every firm: (1) a classification based on its own activity; and (2) a classification based on the technological environment in which it operates. I define three terms to describe the activity of entrepreneurial firms:

(1) tech-maker entrepreneurship;

(2) Kirznerian entrepreneurship; and

(3) performance entrepreneurship.

Every firm in the sample will have one or more of these three classifications.

Tech-maker entrepreneurship is entrepreneurship by a firm involving a new product or service offering based on technological innovation accomplished by the firm itself. A firm designing, developing, manufacturing and selling a new high-tech widget is an example of tech-maker entrepreneurship. Kirznerian entrepreneurship is entrepreneurship involving a new product offering that was possible without new technology developed by the firm. In these definitions, new means not offered before in the market. 
Performance entrepreneurship concerns entrepreneurship involving a firm (1) selling the same basic product or service as the competition or (2) selling a new product or service developed by a third party. It is not necessary that the performance entrepreneurship firm achieves any level of performance excellence, only that the firm strives for market share while competing on (1) price, (2) quality, (3) service or (4) product differentiation (better features of an existing product that are obviously desirable).

Separate and distinct from this classification based on firm activity, I provide a second classification of firms based on their technological environment. I have two classifications for the technological environment of firms. The term tech-enabled entrepreneurship means efforts of a firm that require recent technological innovations developed by others, not the firm itself. A firm selling and installing or servicing a new high-tech widget recently developed by a different firm is an example of tech-enabled entrepreneurship. Recent means widely available for the benefit of the firm or its customers no more than eight years before firm founding. Eight years is a number I selected based on the amount of time it could take a firm to recognize an opportunity and procure necessary resources for a firm. The alternative calculation the tech-enabled entrepreneurship is simply not tech-enabled.

In Chapter III, I will place boundaries around these terms so that they can be measures in my hypotheses testing. Figure 1 depicts the different classifications.

Insert Figure 1 about here. 
Figure 1 depicts (1) the three classifications that a firm can have for its own conduct, (2) the two classifications that a firm can have based on its environment, and (3) the possible interactions of these classifications. The three circles represent the three types of ventures based on firm activity: tech-maker, Kirznerian and performance entrepreneurship. Under any of these classifications, a firm is also classified as either (a) tech-enabled or (b) not tech-enabled. I use the vertical line to segregate (a) tech-enabled and (b) not techenabled ventures, with each circle having the two separate regions (half circles) designated with capital letters.

Firms in the spaces to the right of the vertical line are tech-enabled firms (in spaces B, D or F); and firms to the left of the line are not tech-enabled firms (in spaces A, C or E). Performance entrepreneurship firms do not overlap Kirznerian and tech-maker entrepreneurship firms because they do not have new products or customer delivery methods that they developed themselves, and the other firms do. The horizontal line in Figure 1 is a border between firms that do and firms that do not have a new product or customer delivery method that they developed themselves. The firms that are the main subject of the research question are in space F. In space F, the firms have not developed any new product offering, but their business model depends on recent technological developments of others.

\section{$\underline{\text { Resource-Based View }}$}

The theory developed herein is grounded in the resource-based view (RBV) of strategy. A focus of resource-based view strategy is competitive advantage which is defined as the accumulation of idiosyncratic, costly (or impossible) to copy resources controlled by a firm that give a firm competitive advantage (Barney, 1997). 
When possible, a firm should strive to achieve and maintain sustainable competitive advantage which is defined as a value-creating strategy that a firm is implementing (1) that is not being simultaneously implemented by the competition and (2) wherein the competition and potential competition are not able to duplicate the benefits arising out of the strategy (Barney, 1991).

A firm goal under RBV is to acquire a collection of resources that are worth more collectively than the cost of acquiring the individual resources (Barney, 1986). The development of operations and marketing know-how in a new market can be a critical part of this effort

While the term resources includes tangible goods and cash, it also includes knowledge, information, know-how, skills, goodwill and other intellectual property. Acquiring sustainable competitive advantage usually involves a combination of multiple types of resources.

\section{Performance Entrepreneurship Prevalence}

Firms in a performance entrepreneurship venture generally compete on product quality, marketing and/or price. Business opportunity can arise from operating efficiency of operations (Hammer and Champy, 1993; Hammer \& Stanton, 1995; Hammer, 1996; Hammer, 2001; Hammer, 2004; Hammer \& Hershman, 2010;). Under RBV, firms can create value by accumulating the resources to function efficiently. Michael Hammer (2004, p. 84) describes an example of a firm achieving success without an innovative new product:

In 1991, Progressive Insurance, an automobile insurer based in Mayfield Village, Ohio, had approximately $\$ 1.3$ billion in sales. By 2002, that figure 
had grown to $\$ 9.5$ billion. What fashionable strategies did Progressive employ to achieve sevenfold growth in just over a decade? Was it positioned in a high-growth industry? Hardly. Auto insurance is a mature, 100-yearold industry. . . Did it diversify into new businesses? No, Progressive's business was ... consumer auto insurance. Did it go global? Again, no...

Neither did it grow through acquisitions or clever marketing schemes. For years, Progressive did little advertising, and some of its campaigns were notably unsuccessful. It didn’t unveil a slew of new products. Nor did it grow at the expense of its margins, even when it set low prices. . The company's growth has not only been dramatic — it is now the country's third largest auto insurer-it has also been profitable.

... By offering lower prices and better service than its rivals, it simply took their customers away. And what enabled Progressive to have better prices and service was operational innovation, the invention and deployment of new ways of doing work.

Hammer defines the term operational innovation which is narrower than the term performance entrepreneurship. However, operational innovation is a possible component of performance entrepreneurship, probably a dominant component of performance entrepreneurship. Going back further in time, Progressive is an example of performance entrepreneurship because the whole business plan of Progressive from the start was to sell the exact same automobile insurance as the competition to certain high-risk drivers, but at a better price than the competition. 
A term commonly used to describe competing on operational innovation is faster better cheaper. The three terms have been used in a variety of orders such as faster cheaper better (Hammer \& Hershman, 2010). . Hammer (2004) predicted that the pursuit of faster better cheaper would be the driving force of the modern economy. Hammer (2004) opined that a central force in business innovation will be the quest for operational innovation. In other words, competition to be faster, better and/or cheaper than the competition, not necessarily competition to come up with a clever new product.

A fact of US life in modern times that drives this desire for faster better cheaper is global competition. Particularly competition from countries with low cost labor, driving down pricing of goods. Moreover, the global competition adds actors competing for customers, thereby intensifying price competition.

Another factor that drives down the cost of goods and services and thereby creates a resulting need for faster better cheaper is the knowledge of consumers (Hammer, 1997). The modern consumer today can easily compare pricing and features of goods and services on the internet in ways that were not possible 30 years ago. Under these circumstances, there is intensified price competition creating a need to be price competitive, and in turn creating a need for faster better cheaper. Commercial purchasers now enjoy the same technology.

Yet another factor is increased competition via the internet. Before the internet, usually if a consumer wanted to buy an item, the consumer usually bought it from a local merchant, and the local merchants competed with each other. Now in the age of the internet, often the consumer can buy the item from a local merchant, or a variety of e commerce vendors. The e commerce vendors come from around the globe. The local 
merchant now has to be competitive with the new actors, thereby tightening price competition and in turn creating a need for faster better cheaper.

Hammer (2004) considered operational efficiency as a source of opportunity in the modern economy for two more reasons: (1) corporate management weak spots; and (2) rapid technological innovation. Hammer (2004) considered operations as a possible weakness in large established firms because their leadership is often dominated by marketing and finance people, not operations people. This weakness arguably enables opportunities for performance entrepreneurs to compete against firms with operations challenged management by employing faster better cheaper efforts.

Entering an established market is difficult. However, if the management of the incumbent firms in an industry are not operating efficiently, there can be entrepreneurial opportunities for a new firm operating efficiently. Under Hammer's view, these opportunities may exist frequently because of management steeped in marketing and finance skills, but not operations skills.

Further, Hammer (2004) envisioned rapid technological innovation enabling operational efficiency and thereby enabling business opportunities based on the newly available technology enabled efficiencies. Changed circumstances resulting from technological advances often mean that what was the most efficient way to do things yesterday is no longer the most efficient way today because tasks can be done more efficiently today with the new technology. Rapidly changing technology means rapidly developing opportunities for performance entrepreneurs. 
All these opportunities enabled by corporate weak spots, rapidly changing technology and the market conditions described above are opportunities for the performance entrepreneur. The quest for faster better cheaper creates entrepreneurial opportunity at two levels. First, there is opportunity for an entrepreneurial firm to excel by making its own operations efficient. Second, there is opportunity for an entrepreneurial to launch ventures improving the efficiency of their clients. These are opportunities ripe for performance entrepreneurs.

Although seldom mentioned in the recent entrepreneurship literature, a recognized basis for entrepreneurial opportunity is decreasing costs of production (Fiet 2002). Holcombe (2003) places factors that generate entrepreneurial opportunities in three categories: (1) factors that disequilibrate the market; (2) factors that enhance production possibilities; and (3) entrepreneurial activity that creates other entrepreneurial opportunity.

Holcombe's second category - - factors that enhance production - - is not limited to manufacturing. He gives a financial services example to illustrate the point. Before modern low cost, long distance transmission of voice and other data, it was not practical to have low cost, national brokerage chains. With the advent of low-cost data transmission, low cost national financial service firms developed.

Hammer's views are consistent with: (1) Holcombe's second source of entrepreneurial opportunities: factors that enhance production possibilities; and (2) Fiet's view that lowering costs is a source of entrepreneurial opportunity. Hammer's operational innovation is a factor that enhances production capabilities - - one of Holcombe's factors. Hammer's view that innovation will drive operational efficiency is also consistent with Fiet's view that lowered costs is a source of opportunity. 
An analysis of the prevalence of performance entrepreneurship ("PE”) firms among IPO firms requires a brief discussion of tech-maker ("TM") and Kirznerian ("KN") firms. The prevalence of PE firms among IPO firms equals $\mathrm{PE} /(\mathrm{PE}+\mathrm{TM}+\mathrm{KN})$. Consequently, the prevalence performance entrepreneurship firms requires at least some analysis of the number of tech-maker and Kirznerian firms. They are part of the equation. Below is a brief discussion of why the number of Kirznerian and tech-maker firms may not be increasing.

In order to make it to the IPO stage, generally a firm has to attain significant success and lasting sustainable advantage. I submit that Kirznerian ventures will seldom reach the IPO stage because the arbitrage opportunities that Kirznerian ventures rely upon often are short lived and therefore do not generate the possibility of a sustainable competitive advantage.

Arguably, tech-maker firms making the IPO ranks should be outnumbered by performance entrepreneurs making the IPO ranks. A single technology breakthrough can generate multiple entrepreneurial opportunities (cf. Schumpeter, 1934). This multiplier effect suggests that tech-maker firms should be outnumbered by performance firms. Moreover, some theory says that technological innovation is becoming the domain of large established corporations, not entrepreneurial firms (Acs \& Audretsch, 2003; Schumpeter, 1942; Galbraith, 1956). This shift could further reduce the number of tech-maker firms.

Additionally, funding is becoming more of an issue for tech-maker firms. Entrepreneurs must obtain financing to realize their opportunities (Baeyens and Manigart, 2003). The dominant funder of high growth tech-maker firms - - VC firms - - are starting to shy away from tech-maker firms (Ewens et al., 2014; Kerr \&Nanda, 2014, Kerr et al., 
2014). CVC is partially filling the void from reduced VC funding for tech-maker firms, but it does so with takeover motives cutting off IPO attainment for some acquired firms (Basu et al., 2011; Benson and Ziedonis, 2010; Chesbrough, 2002, Dimitrova, 2015; Dushnitsky and Lenox, 2006, Dushnitsky, 2012; Dyer, Kale and Singh, 2004; Hellmann, 2002, 2005; Ivanov\& Xie, 2010; Kaplan \& Stromberg, 2004; Masulis and Nahata, 2011; Rohm, 2018; Wieland, 2005). The reduced funding arguably reduces the number of techmaker firms achieving an IPO.

Considering: (1) Hammer's view and other circumstances arguably driving up the number of performance entrepreneurship firms; as well as (2) possible downward pressure on the number of tech-maker firms resulting from decreased funding and increasing complexity; and (3) arguably lackluster potential opportunity for the Kirznerian firm to reach the IPO stages, I propose this hypothesis:

Hypothesis 1: Most firms that make it to the US IPO stage are firms pursuing performance entrepreneurship ventures, not Kirznerian or tech-maker ventures.

I submit that the performance entrepreneur is the dominant form of highly successful entrepreneurs.

$\underline{\text { Tech-enabled/Performance Entrepreneurship Prevalence \& Potential Success }}$

Next, I narrow my focus from all performance entrepreneurs to a limited subset of performance entrepreneurs. I look at the performance entrepreneurs who operate in a techenabled environment - - the subjects of the research question. Under the definitions of this dissertation, they are tech-enabled performance entrepreneurs.

The high growth of firms reaching the IPO stage enable extraordinary returns for early investors. Under the resource-based view (RBV), extraordinary returns generally are 
not possible unless there is considerable uncertainty regarding the value of the inputs (Amit \& Shoemaker, 1993. Barney, 1986, 1988). High risk in early investment in firms that achieve high-growth enables extraordinary returns.

The tech-enabled environment contains considerable uncertainty about the value of the inputs. A tech-enabled venture can be selling or using a new technology. Regardless of whether the tech-enabled opportunity is to (1) utilize a new product or service enabled by recent technological innovation or (2) sell a new product or service enabled by recent technological innovation, there is considerable uncertainty. There is not only the uncertainty about market acceptance of the new product or service, but also uncertainty about the reliability of the new product or service.

There is risk that the new technology that worked fine in the laboratory before going to market does not work fine when put to use in the real world. Further, there is uncertainty about the practicalities of everything involved with the product or service. Also, there is uncertainty about the ability of the entrepreneur to perform as necessary with the new technology.

In the tech-enabled/performance entrepreneurship setting, often the entrepreneurial opportunity is obvious to those skilled in the subject discipline. Consequently, many firms enter the market space in swarms and then there is competition between the firms on either cost/price and/or product differentiation (cf. Schumpeter, 1939). In this type of competitive environment, the firms that prevail in this competition are the firms that can establish a sustainable competitive advantage in cost and/or product differentiation (Porter, 1985). 
A key component of a developing sustainable competitive advantage is learning (Porter, 1985). The firms that generally learn the fastest and learn the most information develop a competitive advantage (cf. Porter, 1985; Holcombe, 2013). The acquired information and knowledge cannot generate extraordinary returns for investors unless it is knowledge and information that the firm has but not its competitors (Barney, 1986, 1988). This concept explains the high-growth opportunities that exist in tech-enabled ventures. If a firm wants to enter a mature market with established actors, the firm is usually behind the established actors in terms of information and knowledge about the specific market. The new entrant faces a major challenge trying to get ahead of the establish actors in terms of knowledge and information about the specific industry.

Conversely, in the tech-enabled scenario, there are no established actors participating in the market space. Consequently, a firm that can learn faster than the other novices it is competing against can develop a sustainable competitive advantage. Due to the lack of established actors with established customers, a firm in the tech-enabled space can achieve high-growth and resulting extraordinary returns for its investors if it learns the nuances of the market faster than the competition. . Thus, in a tech-enabled market a firm can achieve high-growth and reach the IPO pinnacle even though it does not have in innovative new product or service that it developed. This is true even if the firm is in a competitive environment. Competing in a new market without established actors is considered a blue ocean strategy as opposed to a more difficult red ocean strategy with blood in the water from fights with established actors (Kim \& Maubourgne, 2005). Kim's and Maubourgne's (2005) theory says blue ocean strategy is more profitable than red ocean strategy. 
All this theory concerning the opportunity for tech-enabled/performance entrepreneurship firms, and faster better cheaper leads to the following hypotheses:

Hypothesis 2: The prevalence of US IPO firms pursuing ventures that are both performance ventures and tech-enabled ventures is growing.

Hypothesis 3: A substantial percentage of US IPO firms are firms pursuing ventures that are both performance ventures and tech-enabled ventures.

Simply, markets recently enabled by technology will produce opportunity for rapid growth.

\section{Theory Summary}

The entrepreneurship literature has tended to focus on the idea of an innovative entrepreneur developing a novel product or service to create wealth. However, the entrepreneur who does not have any innovative new product or technology that he/she developed, but utilizes new technology developed by others, may be more common and profitable than realized. A key entrepreneurial skill may be to execute/perform/operate better than the competition in competitive markets recently enabled by technological innovations of others. The better performance may be grounded in operational excellence, better customer service, better pricing or other factors. In this setting, entrepreneurial talent is needed to adapt to and utilize the finer points of the new technology.

\section{$\underline{\text { Stratified Research }}$}

I acknowledge that IPO firms are not a representative or generalizable sample of entrepreneurs. However, IPO firms are some of the most successful entrepreneurial firms, if not the most successful. Entrepreneurship scholars consider attaining an IPO as the 
pinnacle of entrepreneurship (Shane, 2003). My interest is not in the entire population of entrepreneurs, but rather in the highly successful entrepreneurs. Various estimates are that about 70 or $80 \%$ of business startups fail. Many firms that survive are making low profit levels or no real profit at all. My research does not concern entrepreneurial firms that failed or marginally profitable firms. I want to look at the nature of ventures pursued by successful entrepreneurs.

Analyzing IPO firms is an excellent way to test my views concerning the dominant type of highly successful entrepreneurship. The pinnacle goal of a VC firm is (1) to invest in an entrepreneurial firm by providing both capital and management advice and then (2) cashing out with a large payout in an IPO or otherwise (Leach \& Melicher, 2015, 2018). VC investment strategy suggests that the typical entrepreneurial firm to invest in by a VC fund is an entrepreneurial firm on the cutting edge of technology attempting some breakthrough - - a firm attempting to proceed in a tech-maker venture. Therefore, by looking at IPO firms, I am looking at the very group of firms that is assumed to be (A) tech-maker ventures, not (B) tech-enabled performance ventures. 


\section{CHAPTER III METHODOLOGY}

\section{Database for Sample of Firms}

The first step of my research was selecting a random sample of IPO firms. To assure that I had a database of a rather complete list of firms to randomly select from for my sample, I selected firms from a database of US IPO firms provided to me by Martin Kenney and Donald Patton dated 2017 and titled: Firm Database of Emerging Growth Initial Public Offerings (IPOs) from 1990 through 2015.

After I randomly selected firms from the database for my sample, I had to go elsewhere to obtain necessary detailed information about the firms in my sample concerning firm activity and firm environment. The main source for detailed specific information concerning firm activity and firm environment was SEC filings (primarily S1 forms) of firms that went through a US IPO during the 1995-2015. I will discuss the Kenney and Martin database before moving on to a discussion of the S-1 forms.

The thoroughness and completeness of this list of firms in Kenney and Martin's Firm Database of Emerging Growth Initial Public Offerings (IPOs) from 1990 through 2015 is explained by the authors. Table 2 is a series of excerpts from a document prepared by the authors to explain the database development, history and breadth of firms included they titled "Guide to the Firm Database of Emerging Growth Initial Public Offerings (IPOs)from 1990 through 2015.” 
Table 2 goes about here

While the database is a result of exhaustive research to gather all relevant firms, it excludes firms going through the IPO process that were not emerging growth firms such as mutual funds and real estate investment trusts (REITS). These restrictions on entry into the database are explained by the authors in Table 3, another set of excerpts of "Guide to the Firm Database of Emerging Growth Initial Public Offerings (IPOs)from 1990 through 2015."

Table 3 goes about here

Table 4 is a list of variables in the database, also from "Guide to the Firm Database of Emerging Growth Initial Public Offerings (IPOs)from 1990 through 2015.”

Table 4 goes about here

\section{$\underline{\text { Measures }}$}

There were six key measures in my research. In terms of activity by the subject firm, there will be four possible measures 
Kirznerian venture - An entrepreneurial venture involving: (1) a significantly different (novel) product, service or customer logistics than previously offered by the competition; that (2) would not be possible but for the alertness to existing market conditions, possibly an element of surprise, by the firm to develop the significantly different product, service or customer logistics.

tech-maker venture - An entrepreneurial venture involving: (1) a significantly different (novel) product, service or customer logistics than previously offered by the competition; that (2) would not be possible but for a technological, change developed by the firm. Any such technical invention/innovation must be sophisticated enough to require specialized experience or training in the applicable art of the invention to develop it.

Kirznerian and tech-maker venture - A venture meeting the criteria of both categories.

performance venture - A venture to sell (A) the same basic products or services (possibly with improved features) as the competition through the same customer logistic channels; competing on basis of faster or otherwise preferable delivery, better price, better quality, or an improved version of the product or service or (B) a new product developed by a third party.

In terms of technological environment, specifically the availability of recent technological innovations available to the firm, each firm will have one of two classifications: 
tech-enabled venture - A venture that would not be possible but for: (1) a technological invention/innovation/change developed by a third-party and available to the entrepreneur and/or its customers as need be no more than the eight years prior to the firm founding.

not tech-enabled venture- Not a tech-enabled venture, not a venture that meets the requirements to be a tech-enabled venture.

I classified a firm as tech-maker or Kirznerian if it made any claim at all of such applicable accomplishment in its SEC filings. I classified a firm as tech-enabled only if its business model absolutely required a new technology by a third party. An example of this would be a one product firm bringing a new drug to market that has been licensed to it by a large pharmaceutical firm.

\section{Extracting Data from SEC Documents}

The main SEC document that I reviewed was S-1 filings. It is a reliable source of information. Every firm going public must file an S-1 (or an SB-1 for small businesses) with the U.S. Securities and Exchange Commission (SEC) prior to its initial public stock offering (IPO). The S-1 is a requirement for all firms going public, except certain small firms can instead file an SB-1 which is a slightly simpler version of an S-1. Both forms contain more than adequate information for the purposes of this dissertation. As explained below, the information relied upon by me from the SEC forms tends to be very reliable.

The IPO has two effects on a firm going public. First, it provides the firm with capital for continued expansion. Second, after the IPO, the equity stakes of both management and other pre-IPO investors, (subject to certain lock-up delays) becomes 
liquid. Management and other pre-IPO investors usually agree not to sell their stock until a period after time after the IPO and this is referred to as a lock-up period.

In return though, the firm must conform to the reporting and transparency requirements imposed by the SEC under the Securities Act of 1933. The Securities Act of 1933 requires companies making a public offering of their securities to publicly disclose relevant business and financial information about their company so that potential investors can make an informed investment decision regarding the offering. Specifically, the 1933 Act requires companies going public to file disclosure documents with the Securities and Exchange Commission, the most important of which are the general form S-1 registration statement ${ }^{1}$ and the 424B prospectus.

For my research, there were two key sections of the S-1 that I reviewed: (1) the general business description; and (2) the required disclosure of risks for the investors. Critically for my research, the risk disclosures set forth risks that bear on my tech-enabled determination such as reliance on a third party's technology. These risk disclosure statements in the S-1 must be accurate, or else the firm and its officers could be subject to civil penalties or even criminal penalties for securities fraud.

I will present details of one S-1 statement in this section to illustrate the value, depth and accuracy of an S-1. I will use a firm called Macrogenics' S-1 to illustrate the features of the S-1 form. The S-1 forms had a standard format to them. They all had a similar table ${ }^{1}$ From this point forward, I will generically use the term S-1 to mean both S-1 and SB-1 forms. Both forms contain the same relevant information for purposes of this dissertation. 
of contents. Below is a sample table of contents from the S-1 for a company called Macrogenics:

$\begin{array}{lr}\text { Prospectus Summary } & 1 \\ \text { Risk Factors } & 11 \\ \text { Special Note Regarding Forward-Looking Statements } & 44 \\ \text { Use of Proceeds } & 46 \\ \text { Dividend Policy } & 47 \\ \text { Capitalization } & 48 \\ \text { Dilution } & 50 \\ \text { Selected Consolidated Financial Data } & 52 \\ \text { Management' s Discussion and Analysis of Financial Condition and Results of Operations } & 54 \\ \text { Business } & 76 \\ \text { Management } & 122 \\ \text { Certain Relationships and Related Party Transactions } & 136 \\ \text { Principal Stockholders } & 137 \\ \text { Description of Capital Stock } & 141 \\ \text { Shares Eligible for Future Sale } & 146 \\ \text { Material U.S. Federal Tax Consequences for Non-U.S. Holders } & 148 \\ \text { Underwriting } & 152 \\ \text { Legal Matters } & 159 \\ \text { Experts } & 159 \\ \text { Where You Can Find More Information } & 159\end{array}$

Although the order varies somewhat, the S-1s all have the same items in their table of contents. For purposes of my research, the three sections I used were (1) Prospectus Summary, (2) Risk Factors and (3) Business. The rest of the sections contain a wealth of information for investors but usually were not relevant to my research.

The first section that I always looked at was the Prospectus Summary. An excerpt of Macrogenics Summary is below:

We are a clinical-stage biopharmaceutical company focused on discovering and developing innovative monoclonal antibody-based therapeutics for the treatment of cancer and autoimmune diseases. We generate our pipeline of product candidates from our proprietary suite of next-generation antibody technology platforms, ... The combination of our technology platforms and antibody engineering expertise has allowed us to generate promising product candidates and enter into several strategic collaborations with 
global pharmaceutical and biotechnology companies. These collaborations provide us with funding and allow us to leverage the additional expertise of our collaborators to advance the development of our product candidates.

This summary is not proof of, but suggestive of, two things: (1) even though it is a pharmaceutical company, it may not be a tech-maker because of the description of itself as "clinical stage" and because of its collaborations and (2) it may be tech-enabled because of the collaboration agreements.

The Risk Factors section of the S-1 reveals more information. One warning is:

We may be unable to obtain orphan product designation or exclusivity for some or all of our product candidates. If our competitors are able to obtain orphan product exclusivity for their products that are the same as our product candidates, we may not be able to have competing products approved by the applicable regulatory authority for a significant period of time.

Each warning such as this one is followed by a lengthy discussion of the risk.

The quest for orphan drug status does not prove, but suggests that this may be a circumstance of an IPO firm developing products invented by a large pharmaceutical firm because this arrangement is common with orphan drugs. In the pharmaceutical context, the term develop generally means take an already patented product through FDA testing. Often, the IPO firm is a firm that has no function other than taking a product through the FDA process after a large firm or university has invented the product, not a tech-maker inventing its own product. In this scenario, the IPO firm usually sells or otherwise passes 
off the manufacturing, distribution and sale of the product; and might not even do its own FDA (clinical) testing. It is basically a financing vehicle for the FDA testing.

The following warnings suggest that might be the case here - - not a full-fledged cutting-edge technical firm developing breakthrough technology - - in the language of this dissertation, not a tech-maker

Our existing therapeutic collaborations are important to our business, and future collaborations may also be important to us. If we are unable to maintain any of these collaborations, or if these collaborations are not successful, our business could be adversely affected.

This warning suggests the possibility that the firm may not be the actual inventor of their product if it has collaboration agreements to do R\&D testing for other firms.

Independent clinical investigators and CROs that we engage to conduct our clinical trials may not devote sufficient time or attention to our clinical trials or be able to repeat their past success.

Thus, the firm had only one function, clinical testing, and it contracted even that out.

The following disclosures show the firm had no manufacturing or sales capabilities, and was even relying on third parties to manufacture.

We expect to contract with third parties for the manufacture of our product candidates for clinical testing in the future and expect to continue to do so for commercialization. This reliance on third parties increases the risk that we will not have sufficient quantities of our product candidates or products or such quantities at an acceptable 
cost, which could delay, prevent or impair our development or commercialization efforts.

We currently have no marketing, sales or distribution infrastructure. If we are unable to develop sales, marketing and distribution capabilities on our own or through collaborations, we will not be successful in commercializing our product candidates.

Failure of our third party contractors to successfully develop and commercialize companion diagnostics for use with our product candidates could harm our ability to commercialize our product candidates.

We have incurred significant losses since inception and anticipate that we will continue to incur losses for the foreseeable future. We have no products approved for commercial sale, and to date we have not generated any revenue or profit from product sales. We may never achieve or sustain profitability.

The following warnings demonstrate the financial risks of the firm.

We will require substantial additional funding, which may not be available to us on acceptable terms, or at all, and, if not available, may require us to delay, scale back, or cease our product development programs or operations.

The following warning suggests that the firm may not be working with a new product, but improvement to products that others already have. At a minimum, it strongly suggests that the products are not Kirznerian. 
We face significant competition and if our competitors develop and market products that are more effective, safer or less expensive than our product candidates, our commercial opportunities will be negatively impacted.

The following warnings suggest that the firm may not have a truly new product, only an improvement to an existing product. Moreover, an improved version that is actually designed by and invented somebody else, the licensors of the patents the firm operates under.

We face significant competition and if our competitors develop and market products that are more effective, safer or less expensive than our product candidates, our commercial opportunities will be negatively impacted.

If any product liability lawsuits are successfully brought against us or any of our collaborators, we may incur substantial liabilities and may be required to limit commercialization of our product candidates. If we fail to comply with our obligations under our intellectual property licenses with third parties, we could lose license rights that are important to our business.

There generally cannot be competition for a new product. Moreover, collaborators generally cannot be liable unless they are the inventors of the product. The patent licenses section indicates the firm is operating with products developed by third parties, not their own. 
The firm started when the patented inventions of others that it was using were new technology of others, so it was classified as tech-enabled for its environmental classification. It would be tempting to not classify the firm as performance entrepreneurship instead of tech-maker for its activity, but one part of the S-1 form indicated it should be classified as a tech-maker.

One of the warnings provides:

If we are unable to obtain and enforce patent protection for our product candidates and related technology, our business could be materially harmed.

The firm's business model included possibly obtaining patents for combinations of others' inventions. Since the proposed business model includes patenting some processes learned from the FDA testing by combining inventions of others, I classified this firm as a techmaker. Of note, a patent can be obtained for combinations of already patented inventions of others, and that appears to be the case here. A patent holder of an invention combining patented inventions of others cannot make his or her patented product without licenses from the underlying patent holders, but he or she has the exclusive rights to use the patented invention, unless he or she grants licenses for others to use it.

The firm could be profitable without getting the intended patents. However, since the firm had patents figured in its projected business, I classified it as a tech-maker. I followed my classification rule that a firm is classified as a tech-maker or Kirznerian firm if it has any claim of having a new product, service or customer logistics. This firm was not classified as Kirznerian because it was attempting to develop a product with an obvious demand that others were attempting to develop. 
I illustrated the S-1 format with this pharmaceutical firm for five reasons. First, pharmaceutical firms were the most difficult to classify. Also, the pharmaceutical firm example shows the rich information that can be gleamed from an S-1 form. Third, it is an example of the methodological nature that I went through to classify firms. Fourth, it showed my emphasis and rigor to classify firms as a category contrary to the hypotheses I proposed. Fifth, it shows the collaboration of entrepreneurial firms with large firms, a point not discussed in the entrepreneurship literature.

\section{$\underline{\text { Sample }}$}

To test the hypotheses, I developed a sample of ventures that went through an initial public offering in the U.S. market during 1995-2015. Given that IPO markets experience major fluctuations and considering that there is no such thing as a "typical" IPO year, the time frame selected spans through different periods of IPO activity levels. For example, there was a boom in IPOs leading up to the Dot Com Boom in 2001 and a real decline in IPOs after the 2008 Financial Crisis. For my sample, I gathered a sample at a minimum 525 firms selected from my data source (minimum of 25 per year) from the list of firms in the time period. These firms were randomly selected.

I classified firms in the sample as (1) performance entrepreneurship firms, (2) Kirznerian firms and/or (3) tech-maker firms based on their activity. Further, I classified them as tech-enabled ventures or not tech-enabled based on their technological environment.

For Hypothesis 1, I looked at the prevalence of performance entrepreneurship firms in comparison to the prevalence of firms with the other alternative classifications. 
For Hypothesis 2, I ran regression analyses to assess whether there were significant increases in the prevalence of firms that are both performance entrepreneurship firms and tech-enabled firms. Further, I compared groups of firms from the same different time periods using to see if there are differences between the groups. For Hypothesis 3, I looked at the prevalence of tech-enabled/performance entrepreneurship firms. 


\section{CHAPTER IV}

\section{RESEARCH RESULTS}

I randomly selected firms to produce a sample with 25 or more firms for each of the years 1995 - 2015 except for two years. Two of the years in that timeframe had less than 25 IPOs involving emerging growth firms as defined above. The year 2008 had only ten such IPOs and 2009 had only 14 IPOs. From these two years, I put all the firms going through IPOs in my sample. Thus, 2008 had only 10 firms in the sample and 2009 at only 14 firms in the sample. An explanation of my random selection process is described in Table 5.

Once the sample was selected, I assigned each firm two classifications. As outlined above I assigned each firm a classification based on the firm's activity and a second classification for its technological environment. Next, I computed the prevalence of the different classifications in each of the years $1995-2015$.

Generally, I expected a low prevalence of performance entrepreneurship firms in the early years (1990s) with the prevalence of the performance entrepreneurship firms growing over the 21 years. This expectation is inherent in my hypotheses. This expectation was based on an assumption that turned out to be wrong. I believed that the faster better cheaper phenomenon was just starting in the early years and had growing momentum over the 21 years. Thus, I expected a low prevalence of performance entrepreneurship firms in the early years and a high prevalence in later years. 
The research results support the expectation of a high prevalence of performance entrepreneurial firms in later years. However, the results contradict the expectation of a low prevalence performance entrepreneurship firms in the early years of the sample. Looking at Figures 2-4, it can be seen that there are no real trends over the timeframe.

Table 6 is a summary setting forth the prevalence of the different classifications of firms for each year. As indicated in Table 6, the prevalence of performance entrepreneurship firms was already high in 1995 at $85 \%$. This high percentage of performance entrepreneurship had a temporal aspect to it. From 1995 to 2000, the ranks of the IPO firms were dominated by firms getting into ventures related to the new technology, the Internet. These firms were not firms attempting to develop new technology, but instead firms attempting to build businesses around use of the technology.

However, even after the dot.com bubble burst in 2001, the prevalence of performance entrepreneurship firms remained high. At the same time, the prevalence of tech-maker firms remained low. Figure 2 is a chart showing the prevalence of tech-maker firms for each of the years and Figure 3 is a chart showing the prevalence of performance entrepreneurship firms. Figure 4 is a chart showing the prevalence of tech-enabled/ performance firms. The chart shows that the prevalence of these firms remained relatively steady.

Going beyond the sample for this dissertation and considering the actual percentage of tech-maker firms among the population of all firms in the winter in IPO in the timeframe $1995-2015$, the $16.0 \%$ figure inflates the actual percentage of tech-maker firms. This is because the annual numbers of IPO firms in the earlier stages of the $1995-2015$ timeframe were large compared to the annual number of firms in the later years and the percentage of 
tech-maker firms were low in the early years. An accurate assessment of tech-maker firms would require a weighting of the samples for the various years in this would drive down the percentage of tech-maker firms because there were large numbers of IPOs in the early years of the time frame while at the same time there were very low percentages of techmaker firms

Looking at figure 2, one can see that there is no decline in tech-maker firms over the sample timeframe. Actually, there is a slight uptick in the prevalence of tech-maker firms in the last three years of the sample timeframe. This increase was driven by a surge in pharmaceutical IPOs. In the 2013 - 2015 timeframe, roughly $35 \%$ of the IPOs were pharmaceutical. I briefly looked at material on this surge and could not find a concrete reason for this surge. Business journals suggested one of two reasons for the surge: (1) recent scientific breakthroughs in genetics that are available to the public have generated new pharmaceuticals based on the recently developed genetic science; and (2) portions of the VC industry gearing up with extra pharmaceutical expertise to invest in pharmaceutical firms. Regardless, prevalence of tech-maker firms remained low averaging $26 \%$.

The percentage of tech-maker firms $(26 \%)$ is lower than the percentage of pharmaceutical firms (35\%) for two reasons: (1) not all pharmaceutical firms are techmaker firms - - some market drugs invented by other parties under patent licenses or assignments from the inventors; and (2) almost all tech-maker firms are in the pharmaceutical space.

There was a real variety of performance entrepreneurship ventures. The lineup included coal mines, sand mines, gold mines, oil producers, natural gas producers, natural gas processors, natural gas transporters, commercial banks, consumer banks, mortgage 
companies, insurance companies, brick and mortar retailers and wholesalers, steel manufacturers, contract manufacturers, homebuilders, clinics, temporary staff agencies, outsourcing operations, medical groups and others. The IT venture was the most common type of performance entrepreneurship venture.

Three technologies were the most common source of tech-enabled ventures: (1) genetic science, (2) fracking technology and (3) far and away the most common, the internet. Genetic science was behind many of the pharmaceutical firms. While better than half of the pharmaceutical firms were

The tech-maker venture category was dominated by pharmaceutical firms. Some of the pharmaceutical firms were not classified as tech-maker because they were marketing drugs invented by others. It is relevant to note that pursuant to my measures, if a firm made any claim at all of having a hand in inventing a product, I classified it as tech-maker.

Interestingly, many of these tech-maker firms were working in collaboration with large pharmaceutical firms. It sometimes was not clear who was the real inventor (originator) of the subject product when the IPO firm was collaborating with a big pharma firm on research. Consistent with my scoring guidelines, I scored these unclear situations as tech-makers, even though they may not have really been tech-makers. Consequently, the real prevalence of tech-maker firms may be lower than reported in the results for this reason.

The risk disclosures show a strong link between Big Pharma and the entrepreneurial firms. The following risk disclosure by an IPO firm Neose discloses the tightness of this link that occurred repeatedly in the pharmaceutical setting: 
Dependence on Abbott; Dependence on Other Collaborative Partners. The Company's strategic alliance with Abbott provides, in part, for the receipt by the Company of certain license fees, milestone payments, and, if commercialization occurs, royalty payments. The Company has derived substantially all of its revenues to date from its strategic alliance with Abbott and anticipates that payments from Abbott will constitute all or substantial portion of its revenues for the next several years.

I classified this firm as a tech-maker, even though it had its research funded by Abbott, had plans to have Abbott market its drugs and had all of its revenue received from Abbott. Following my classification rules, I classified it as a tech-maker because it was inventing its own products.

With some IPO firms though, the nature of the alliance and collaboration precluded a tech-maker designation. The risk disclosures of an IPO firm Ventrus confirmed it did not have a product that it developed on its own. This disclosure confirms that it was not the inventor of its only products:

Our license agreement with S.L.A. Pharma is subject to termination if this offering is not completed by September 30, 2010 or if a third party wishes to license VEN 307 and VEN 308 in certain events.

We have in-licensed the rights to VEN 307 and VEN 308 from S.L.A. Pharma. Pursuant to a December 18, 2009 amendment to the license agreement between us, in the event we do not complete this offering by September 30, 2010 with net proceeds of at least $\$ 10$ million, S.L.A. Pharma may terminate the license agreement immediately. In addition, S.L.A. Pharma may terminate the license agreement with one month's 
notice in the event that a third party wishes to enter into a license agreement for VEN 307 and VEN 308, provided that within that 30-day period we have not paid all then required payments under the agreement and provided further that S.L.A.

This disclosure shows the control that big pharma exerts over the entrepreneurial IPO firms. Big pharma provides various resources, but with strict conditions.

The evidence does support Hypothesis 1 (that the majority of firms reaching the IPO stage are in fact performance entrepreneurship firms, not tech-maker or Kirznerian). Performance entrepreneurship firms were $83.0 \%$ of the firms, tech-maker firms were $15,9 \%$ and Kirznerian firms were $1.9 \%$. The prevalence of Kirznerian firms was very low. During most years, the sample of firms did not contain any Kirznerian firms. This average in the sample overstates the average percentage of Kirznerian firms (both inside and outside the sample) because of the large number of firms reaching IPOs in the early stages of the 1995 - 2015 timeframe and the high percentage of performance entrepreneurship firms during the early stages.

I ran $\mathrm{z}$ tests to assess whether or not the data is strong enough to say with confidence that the percentage of performance entrepreneurship firms is actually greater than the percentage of Kirznerian firms or tech-maker firms. First, I performed a two sample z test to compare the means of (1) the percentage of performance entrepreneurship firms and (2) the percentage of tech-maker firms. The null hypothesis for this test was that the two means were equal. At a 99\% confidence level, the null hypothesis that the two means are the same was rejected $(\mathrm{p}<.01)$. The figures for this test are set forth in Table 8 . 
Next, I ran a test comparing the percentage of performance entrepreneurship firms and the percentage of Kirznerian firms. Similarly, I set the percentages of the two types of firms being equal as the null hypothesis $(\mathrm{p}<.01)$. At a 99\% confidence level, the null hypothesis that the two means are the same was rejected. The figures for this test are set forth in Table 9. Thus, the testing does not contradict a conclusion that the prevalence of performance entrepreneurship firms (at roughly 83\%) is greater than the prevalence of tech-maker firms (at roughly 16\%) and the prevalence of Kirznerian firms (at roughly $2 \%$ ).

The data did not support Hypothesis 2 (that the prevalence of firms that are both tech-enabled and performance entrepreneurship firms is growing). As previously discussed, contrary to expectations, the prevalence of performance entrepreneurship firms was very high at the beginning of the timeframe. Also, at the outset of the timeframe, the prevalence of tech-enabled firms was substantial ( $42 \%$ on average). This percentage is much higher than the percentage of tech-maker firms (16\%) and Kirznerian (2\%).

However, the data does support Hypothesis 3 (that prevalence of firms that are both tech-enabled and performance entrepreneurship is substantial). The prevalence of techenabled firms was substantial ( $42 \%$ on average). This percentage is much higher than the percentage of tech-maker firms (16\%) and Kirznerian firms (2\%).

To summarize the findings of the data, overarching conclusions that can be reached concerning IPO firms in the timeframe are:

a. the majority of the firms are performance entrepreneurship firms in the sample (approximately 83\%); 
b. tech-maker firms are a small percentage of the firms (approximately 16\%) in the sample;

c. Kirznerian firms are only a very small percentage of the firms (approximately 2 or 3\%);

d. the percentage of tech-enabled firms is high (approximately 49\%) in the sample; and

e. firms that are both tech-enabled and performance entrepreneurship firms are not a majority of the firms, but they are a substantial percentage of the firms (approximately 40\%) in the sample.

Contrary to expectations, there were not trends of increasing prevalence of techenabled firms, trends of increasing prevalence of firms that were both tech-enabled and performance entrepreneurship firms, or trends of decreasing prevalence of performance entrepreneurship firms. At the beginning of the subject timeframe, there are already was (1) a high prevalence of tech-enabled firms and performance entrepreneurship firms coupled with (2) a low prevalence of tech-maker firms. 


\section{CHAPTER V}

\section{DISCUSSION AND CONCLUSIONS}

\section{Theory Contributions}

This dissertation extends the entrepreneurship literature and theory five ways. First, it brings to light a critically important role that entrepreneurs play in bringing benefits of technological advances to society. Although this study does not support the view a view that entrepreneurs are frequent inventors of new technological breakthroughs, it highlights a critical role that entrepreneurs play in bringing technological advances to society. Quite often, the underlying inventors of technological breakthroughs lack expertise in developing the many beneficial uses of its technology. Entrepreneurs feel a critical role by utilizing their niche expertise to bring the benefits of the novel technology to their respective niche markets.

Second, this dissertation extends the entrepreneurship theory by taking a broader look at innovation and shining light on a type of innovation not extensively covered in the modern entrepreneurship literature - - the innovation of faster better cheaper - - incremental innovation.

Entrepreneurship literature focuses on innovation to develop new products to avoid competition - - radical innovation or disruptive innovation which is creating new products

or services However, I note that there are other types of innovation. Another type of 
innovation, incremental innovation is characterized by faster better or cheaper versions of existing products or services, either an improved version of the product or service, better delivery of the same product or service, or offering the same product or service at a better price. These results of this dissertation suggest that incremental innovation may be a common, if not the dominant, innovation utilized by entrepreneurs. This type of innovation has not been covered in the entrepreneurship literature.

Third, this dissertation brings rare empirical evidence to the theoretical debates on the efforts of entrepreneurs to launch ventures. Despite extensive attention paid to the theoretical debate concerning the origins of entrepreneurial ventures and how entrepreneurs select ventures to pursue, empirical research on these topics remains limited. This dissertation contributes new empirical evidence by looking at the ventures pursued by entrepreneurial high-growth firms. By looking at 568 firms that have achieved highgrowth, this dissertation contributes to the literature by giving insight into what highgrowth firms actually do. The field of entrepreneurship cannot advance until an understanding is developed of what entrepreneurs actually do (Aldrich \& Ruef, 2019).

This dissertation contributes to the entrepreneurship literature for a fourth reason - it points out the prevalence and profit potential of the performance entrepreneur. While early scholars may have had definitions of entrepreneurship broad enough to include the performance entrepreneur, the performance entrepreneur has been all but forgotten in the entrepreneurship literature of the last 50 years. This dissertation brings the performance entrepreneur back into the discussion of what entrepreneurship actually is. Finally, this dissertation demonstrates what is not necessary to have a highly successful venture. An innovative novel product or service is not needed. 
This dissertation also extends strategy theory. A critical issue in RBV strategy research is how do firms purchase the resources they need at prices that allow them to create a competitive advantage (Barney, 1986). Barney (1986) opines that the expense of gaining information that is available to the competition does not fall into this category. However, Barney does not offer information on how firms develop valuable information that is private or exactly what it is. This dissertation contributes to strategy literature by empirically showing examples of what the nature of such information can be for entrepreneurs.

Further, this dissertation adds to economics literature by providing some empirical research into Schumpeter theories that have not been tested extensively. Schumpeter (1942) said that technological innovation would increasingly become the domain of large established firms and this dissertation provides some empirical evidence to support this theory. There were only a small percentage of IPO firms that claimed a technological innovation. Schumpeter $(1934,1939,1942)$ opined that entrepreneurial opportunities arise for entrepreneurial firms from exogenous change. Supporting this view of Schumpeter is the data that over $40 \%$ of the IPO firms had a business model that depended on recent technological change.

\section{$\underline{\text { Limitations }}$}

This dissertation has limitations. Although the research is longitudinal covering the time period $1995-2015$, there is a temporal nature to it. The economy is dynamic. Changes to the economy in the future may render the conclusions of this dissertation flawed. Further, this research is limited in geographic scope to firms achieving an IPO in US markets. Although this restriction does not necessarily limit the sample to US based 
firms, it does severely limit the sample to US firms and foreign firms in which US investors will invest. Firms from other countries may operate under different circumstances.

Another limitation is the sample size. Although it is relatively large (568 firms), it could be larger. A larger sample size could produce different results.

The sample generated herein is not a generalizable sample of all entrepreneurs and this is a limitation of the sample However, it is not intended to be a generalizable sample of all entrepreneurs. It is certainly a generalizable sample of IPO firms in the 1995-2015 timeframe and it arguably generalizable to high-growth firms. Although this dissertation may not tell you what is necessary to achieve success as a high growth firm, it surely tells you what is not necessary - - a clever new product that nobody else thought of before.

\section{Practitioner Value}

This research has valuable information for the practitioner. For the aspiring entrepreneur, it gives guidance on what type of venture to pursue, pointing out the lack of a need for a novel product. Further, it can guide the aspiring entrepreneur to consider (1) opportunities arising from technological change and (2) faster better cheaper opportunities. Perhaps more importantly, it points out the danger of not keeping abreast of faster better cheaper.

\section{Future Research}

This dissertation points to directions for future research. Future research could look at change other than technological change generating entrepreneurial opportunities. In reviewing the SEC filings, it became apparent that (1) change other than technological change generates entrepreneurial opportunities and (2) a high percentage of successful 
entrepreneurs are taking advantage of some type of recent change. In the sample, I was not looking for it, but I noticed other types of change frequently being the catalyst for ventures. Future research can follow up in other ways.

First, future studies could look at the prevalence of tech-enabled/performance entrepreneurship firms among non-IPO firms, particularly high-growth firms that do have high-growth, but not enough growth to reach the IPO stage. Second, future studies can be done to update the research in this dissertation.

Third, future research can be done to look at industries that enable high-growth entrepreneurship. In the study, the overwhelming majority of tech-maker firms were in the biotechnology space. Why does this industry spawn so many more IPO firms than the rest of the industries? Is it economies of scale, regulations, taxes, risk/reward tradeoffs desired by investors, location of talent or other factors?

Fourth, future studies could look at the skills required to be a successful techenabled/performance entrepreneur. Although there has been considerable research on the entrepreneur/non-entrepreneur distinctions, there has not been extensive research on the successful/non-successful entrepreneur generally, let alone the traits required to be a successful tech-enabled/performance entrepreneur. 


\section{REFERENCES}

Acs, Z.J., \& Audretsch, D.B. (2003). Innovation and Technological Change. Chapter 4 of Acs and Audretsch Handbook of Entrepreneurship Research. Kluwer Academic Publishers. Printed in Great Britain.

Aldrich, H., \& Ruef, M. (2018). Unicorns, gazelles, and other distractions on the way to understanding real entrepreneurship in the united states. Academy of Management Perspectives, 32(4), 458-472. doi:10.5465/amp.2017.0123

Alvarez, S., \& Barney, J. (2007). Discovery and creation: Alternative theories of entrepreneurial action. Strategic Entrepreneurship Journal, 1(1-2), 11-26. doi:10.1002/sej.4

Alvarez, S., Barney, J., \& Anderson, P. (2013). Forming and exploiting opportunities: The implications of discovery processes for entrepreneurial and organizational research. Organization Science, 24(1), 301-317. doi:10.1287/orsc.1110.0727and creation

Baeyens K, Manigart S. (2003) Dynamic financing strategies: the role of venture capital. Journal of Private Equity 7(1): 50-58.

Baker, T., R. Nelson. (2005). Creating something from nothing: Resource construction through entrepreneurial bricolage. Admin. Sci. Quart. 50(3) 329-366.

Barney, J. (1986). Strategic factor markets: Expectations, luck, and business strategy. Management Science, 32(10), 1231-1241. doi:10.1287/mnsc.32.10.1231

Barney, J. (1988). Returns to bidding firms in mergers and acquisitions: Reconsidering the relatedness hypothesis. Strategic Management Journal, 9(S1), 71-78. doi:10.1002/smj.4250090708

Barney, J. (1991). Firm resources and sustained competitive advantage. Journal of Management, 17(1), 99-120. doi:10.1177/014920639101700108

Barney, J. (1997). Gaining and sustaining competitive advantage. Reading, Mass.: Addison-Wesley Pub.

Barney JB. (2001). Is the resource-based 'view' a useful perspective for strategic management research? Yes. Academy of Management Review 26(1): 41-56. 
Basu, S., Phelps, C., \& Kotha, S. (2011). Towards understanding who makes corporate venture capital investments and why. Journal of Business Venturing, 26(2), 153 171. doi:10.1016/j.jbusvent.2009.07.001.

Benson, D., \& Ziedonis, R. (2010). Corporate venture capital and the returns to acquiring portfolio companies. Journal of Financial Economics, 98(3), 478-499. doi:10.1016/j.jfineco.2010.07.003.

Byers, T., Dorf, R. \& Nelson, A. (2010). Technology Ventures: From Idea to Enterprise. McGraw-Hill Education

Cantillion, R. (1755). Essai Sur La Nature Du Commerce En Général. Henry Higgs, ed. London: Macmillan, 1931.

Chesbrough, H. (2002). Making sense of corporate venture capital. Harvard Business Review, 80(3), 90-9.

Davidsson, P. (2017). Opportunities, propensities, and misgivings: Some closing comments. Journal of Business Venturing Insights, 8, 123-124. doi:10.1016/j.jbvi.2017.09.002

Dimitrova, L. (2015). Strategic acquisitions by corporate venture capital investors. Ssrn Electronic Journal, (2015). doi:10.2139/ssrn.2553786.

Dushnitsky, G. (2012). THE VENTURE. Business Strategy Review, 23(2), 58-60. doi:10.1111/j.1467-8616.2012.00847.x.

Dushnitsky, G., \& Lenox, M. (2006). When does corporate venture capital investment create firm value? Journal of Business Venturing, 21(6), 753-772. doi:10.1016/j.jbusvent.2005.04.012.

Dyer, J., Kale, P. \& Singh, H. (2004). When to Ally \& When to Acquire. Harvard Business Review. 82. 108-15

Ewens, M., Nanda, R. \& Rhodes-Kropf (2014) Cost of Experimentation and the Evolution of Venture Capital. Working Paper.

Fiet, J. (2002). The systematic search for entrepreneurial discoveries. Westport, Conn.: Quorum Books.

Foss, N., \& Klein, P. (2012). Organizing entrepreneurial judgment: A new approach to the firm. Cambridge: Cambridge University Press.

Galbraith, J. (1956). American Capitalism: The Concept of Countervailing Power, revised edition. Boston, MA: Houghton Mifflin. 
Gartner WB. (1985). A conceptual framework for describing the phenomenon of new venture creation. Academy of Management Review 10: 696-706.

Hammer, M., \& Champy, J. (1993). Reengineering the corporation: A manifesto for business revolution. Business Horizons, 36(5), 90-91. doi:10.1016/S00076813(05)80064-3

Hammer, M. (1997). Beyond Reengineering: How the Process-Oriented Organization is Changing Our Work and Our Lives. Harper Business.

Hammer, M., \& Champy, J. (2001). Reengineering the corporation : A manifesto for business revolution. New York: Harper Business.

Hammer, M. (2001). The agenda : What every business must do to dominate the decade ( $1^{\text {st }}$ ed.). New York: Crown Business.

Hammer, M. (2004). Deep change: How operational innovation can transform your company - operational innovations fuel extraordinary results -- they can destroy competitors and shake up entire industries. so why aren't more companies taking advantage of their power? Harvard Business Review, 04, 84.

Hammer, M. (2004). Deep change -- how operational innovation can transform your company. IEEE Engineering Management Review, 32(3), 42.

Hammer, M., \& Hershman, L. (2010). Faster, cheaper, better : The 9 levers for transforming how work gets done (1st ed.). New York: Crown Business.

Hammer, M., \& Stanton, S. (1995). The reengineering revolution : A handbook (1st ed.). New York, N.Y.: Harper Business

Hellmann, T. (2002). A theory of strategic venture investing. Journal of Financial Economics, 64(2), 285-314. doi:10.1016/S0304-405X(02)00078-8.

Holcombe, R. (2003). Progress and entrepreneurship. The Quarterly Journal of Austrian Economics, 6(3), 3-26. doi:10.1007/s12113-003-1021-3

Holcombe, R. (2013). Firms as knowledge repositories. The Review of Austrian Economics, 26(3), 259-275. doi:10.1007/s11138-011-0165-1

Ivanov, V., \& Xie, F. (2010). Do corporate venture capitalists add value to start-Up firms? evidence from IPOs and acquisitions of VC-Backed companies. Financial Management, 39(1), 129-152. doi:10.1111/j.1755- 053X.2009.01068.x. 
Kaplan, S., \& Stromberg, P. (2004). Characteristics, contracts, and actions: Evidence from venture capitalist analyses. The Journal of Finance, 59(5), 2177-2210. doi:10.1111/j.1540-6261.2004.00696.x.

Kenney, M. \& Patton, D. (2017). Firm Database of Emerging Growth Initial Public Offerings (IPOs) from 1990 through 2015.

Kenney, M. \& Patton, D. (2017). Guide to the Firm Database of Emerging Growth Initial Public Offerings (IPOs)from 1990 through 2015.

Kerr, W., \& Nanda, R. (2014). FINANCING INNOVATION. Working Paper Series, 20676(20676).

Kerr, W., Nanda, R., \& Rhodes-Kropf, M. (2014). ENTREPRENEURSHIP AS EXPERIMENTATION. Working Paper Series, 20358(20358).

Kim, W., Mauborgne, R., \& Mauborgne, R. (2005). Blue ocean strategy : Blue ocean strategy : How to create uncontested market space and make the competition irrelevant / how to create uncontested market space and make the competition irrelevant. Boston, Mass.: Harvard Business School Press

Kirzner I. (1973). Competition and Entrepreneurship. University of Chicago Press: Chicago, IL, and London.

Kirzner IM. (1997). Entrepreneurial discovery and the competitive market process: an Austrian approach. Journal of Economic Literature 35(1): 60-85.

Kirzner, I., \& Institute of Economic Affairs (Great Britain). (1997). How markets work : Disequilibrium, entrepreneurship and discovery (Hobart paper, no. 133). London: Institute of Economic Affairs.

Leach, J., \& Melicher, R. (2015). Entrepreneurial finance. (Fifth edition). Boston, Massachusetts: Cengage Learning.

Leach, J., \& Melicher, R. (2018). Entrepreneurial finance. (Sixth edition). Boston, Massachusetts: Cengage Learning.

Masulis, R., \& Nahata, R. (2009). Financial contracting with strategic investors: Evidence from corporate venture capital backed IPOs. Journal of Financial Intermediation, 18(4), 599-631. doi:10.1016/j.jfi.2009.06.001.

Menger, C. (1871). Principles of Economics. Auburn, Ala.: Mises Institute, 2007.

Mises, L. (1949). Human action: A treatise on economics. New Haven: Yale University Press. 
Porter, M. (1985). Competitive advantage : Creating and sustaining superior performance. New York: Free Press.

Ramoglou, S., \& Tsang, E. (2016). A realist perspective of entrepreneurship: Opportunities as propensities. Academy of Management Review, 41(3), 410434.doi:10.5465/amr.2014.0281

Rohm, P. (2018). Exploring the landscape of corporate venture capital: A systematic review of the entrepreneurial and finance literature. Management Review Quarterly, 1-41, 1-41. doi:10.1007/s11301-018-0140-z.

Sarasvathy SD. (2001). Causation and effectuation: toward a theoretical shift from economic inevitability to entrepreneurial contingency. Academy of Management Review26(2): 243-263.

Schumpeter, J. (1934). The theory of economic development. Cambridge, MA: Harvard University Press.

Schumpeter, J. (1939). Business cycles : A theoretical, historical, and statistical analysis of the capitalist process. New York: McGraw-Hill Book Company

Schumpeter, J., (1942). Capitalism, socialism and democracy. New York: Harper and Row.

Shane, S. (2003). A general theory of entrepreneurship: The individual-opportunity nexus (New horizons in entrepreneurship). Cheltenham, UK: E. Elgar.

Shane, S. (2016) Lecture at a midwestern university.

Tong, T., \& Li, Y. (2011). Real options and investment mode: Evidence from corporate venture capital and acquisition. Organization Science, 22(3), 659-674. doi:10.1287/orsc.1100.0551.

Venkataraman, S. (1997). The distinctive domain of entrepreneurship research. In J. Katz and R. Brockhaus, eds., Advances in Entrepreneurship, Firm Emergence, and Growth, Volume III. Greenwich, CT: JAI Press.

Wieland, K. (2005). More than money: When vendors venture, their priorities differ from traditional VCs. Telecommunications Magazine (April 6). 
FIGURE 1- Venn Diagram of Firms

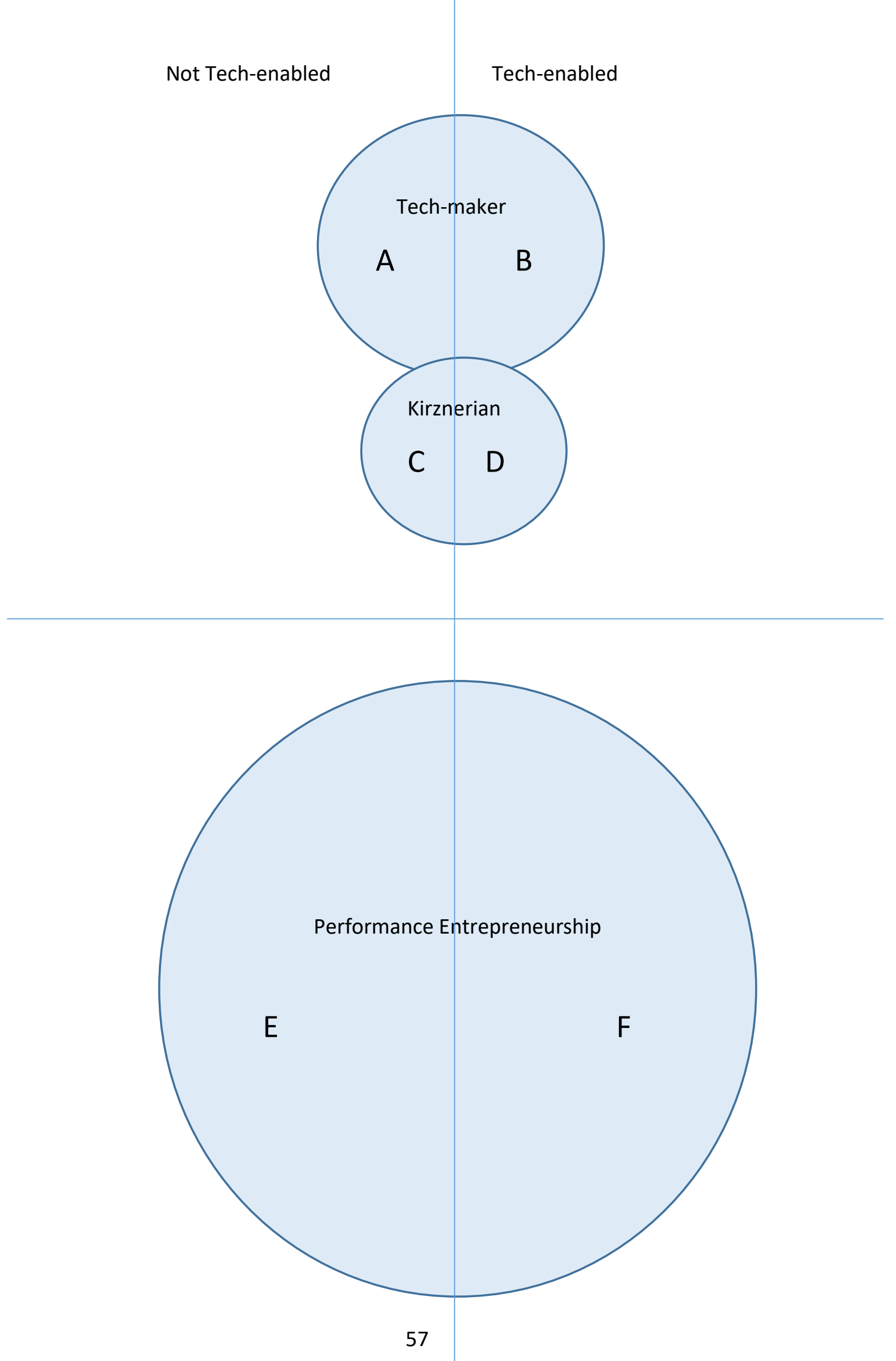


Figure 2

Prevalence of Tech-maker Firms

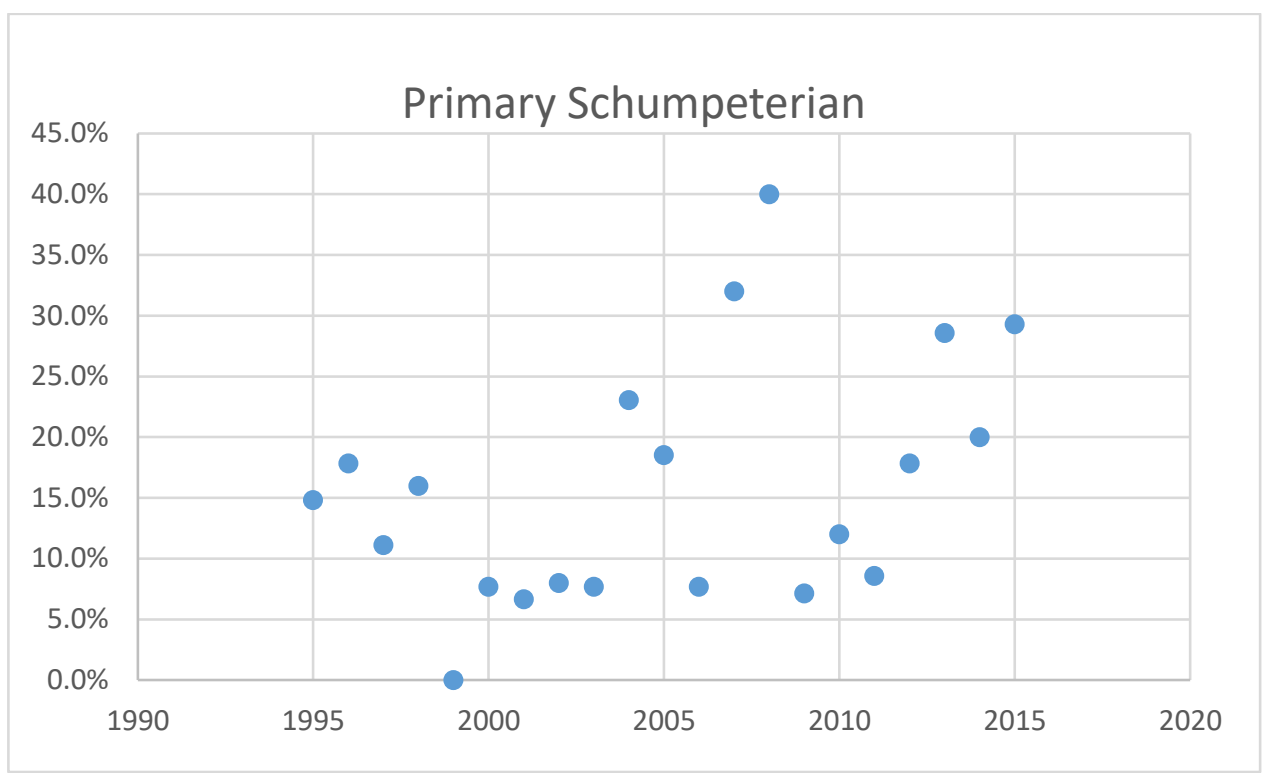


Figure 3

Prevalence of Performance Entrepreneurship Firms

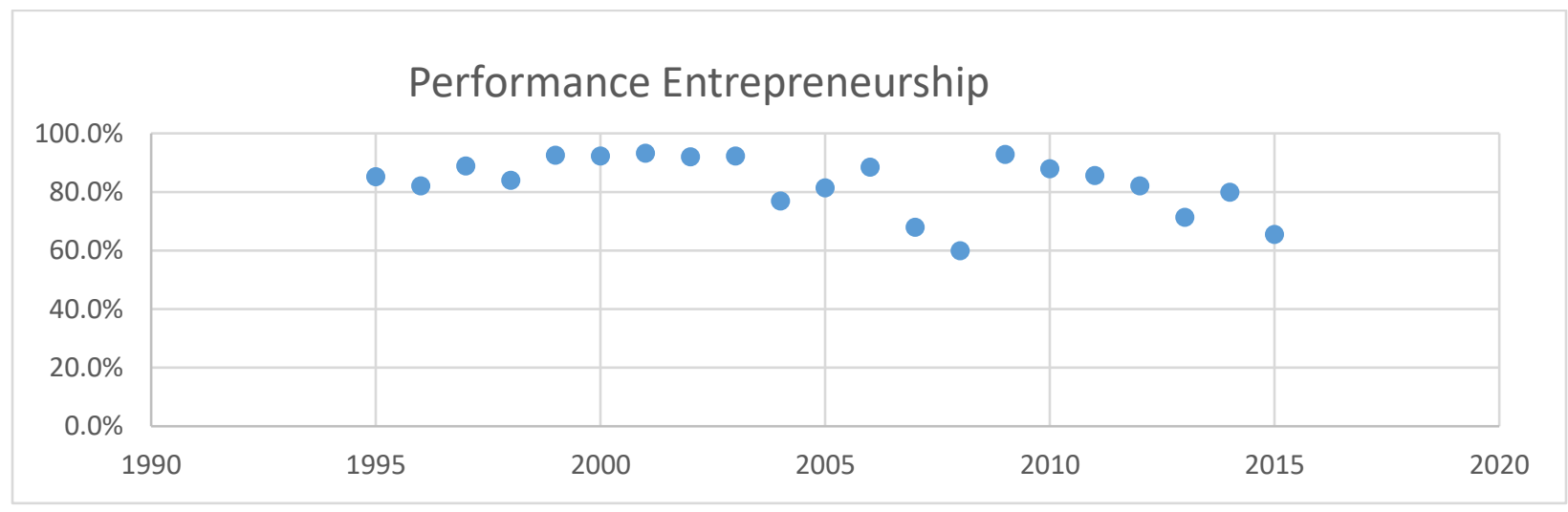


Figure 4

Prevalence of firms that are both Tech-enabled and Performance Entrepreneurship

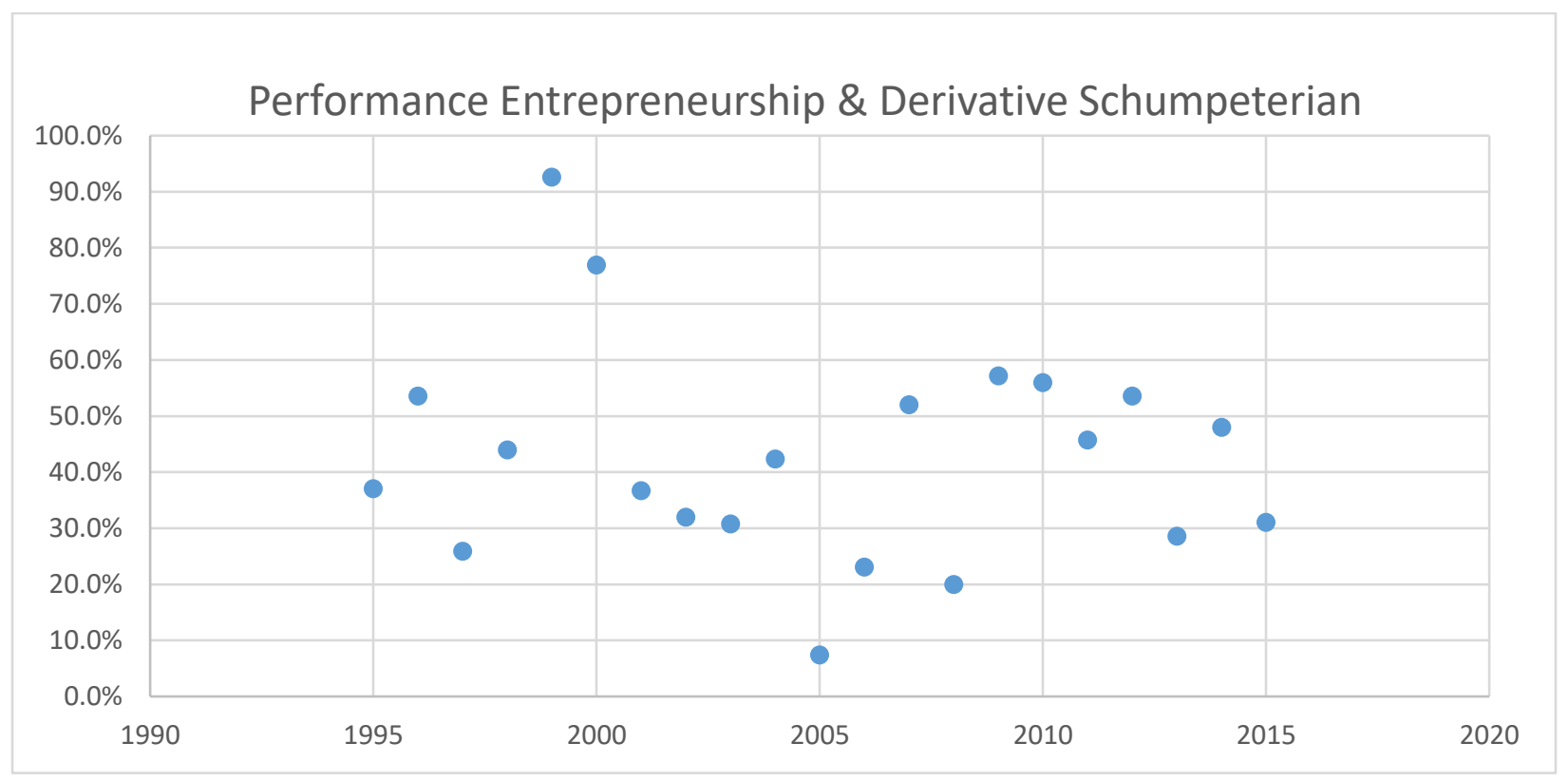


Table 1

US Patents

\begin{tabular}{|c|c|c|c|c|c|c|c|}
\hline \multicolumn{8}{|c|}{$\begin{array}{c}\text { Table } 1 \\
\text { US Patents }\end{array}$} \\
\hline $\begin{array}{l}\text { Calendar } \\
\text { Year }\end{array}$ & $\begin{array}{c}\text { Utility } \\
\text { Patent } \\
\text { Applications }\end{array}$ & $\begin{array}{c}\text { Design } \\
\text { Patent } \\
\text { Applications }\end{array}$ & $\begin{array}{c}\text { Plant } \\
\text { Patent } \\
\text { Applications }\end{array}$ & $\begin{array}{c}\text { Utility } \\
\text { Patents }\end{array}$ & $\begin{array}{l}\text { Design } \\
\text { Patents } \\
\end{array}$ & $\begin{array}{c}\text { Plant } \\
\text { Patents }\end{array}$ & $\begin{array}{l}\text { Patents } \\
\text { to Foreign } \\
\text { Residents } \\
\end{array}$ \\
\hline 2015 & 589,410 & 39,097 & 1,140 & 298,407 & 25,986 & 1,074 & 169,763 \\
\hline 2014 & 578,802 & 35,378 & 1,063 & 300,678 & 23,657 & 1,072 & 166,999 \\
\hline 2013 & 571,612 & 36,034 & 1,406 & 277,835 & 23,468 & 847 & 154,891 \\
\hline 2012 & 542,815 & 32,799 & 1,149 & 253,155 & 21,951 & 860 & 142,180 \\
\hline 2011 & 503,582 & 30,467 & 1,139 & 224,505 & 21,356 & 823 & 125,998 \\
\hline 2010 & 490,226 & 29,059 & 992 & 219,614 & 22,799 & 981 & 122,694 \\
\hline 2009 & 456,106 & 25,806 & 959 & 167,349 & 23,116 & 1,009 & 96,677 \\
\hline 2008 & 456,321 & 27,782 & 1,209 & 157,772 & 25,565 & 1,240 & 92,929 \\
\hline 2007 & 456,154 & 27,752 & 1,049 & 157,282 & 24,062 & 1,047 & 89,007 \\
\hline 2006 & 425,967 & 25,515 & 1,151 & 173,772 & 20,965 & 1,149 & 93,942 \\
\hline 2005 & 390,733 & 25,553 & 1,222 & 143,806 & 12,951 & 716 & 75,046 \\
\hline 2004 & 356,943 & 23,975 & 1,221 & 164,290 & 15,695 & 1,016 & 87,051 \\
\hline 2003 & 342,441 & 22,602 & 1,000 & 169,023 & 16,574 & 994 & 88,258 \\
\hline 2002 & 334,445 & 20,904 & 1,144 & 167,331 & 15,451 & 1,133 & 87,101 \\
\hline 2001 & 326,508 & 18,280 & 944 & 166,035 & 16,871 & 584 & 85,173 \\
\hline 2000 & 295,926 & 18,292 & 797 & 157,494 & 17,413 & 548 & 78,871 \\
\hline 1999 & 270,187 & 17,761 & 863 & 153,485 & 14,732 & 420 & 74,877 \\
\hline 1998 & 243,062 & 17,107 & 720 & 147,517 & 14,766 & 561 & 72,398 \\
\hline 1997 & 215,257 & 16,546 & 621 & 111,984 & 11,414 & 394 & 54,107 \\
\hline 1996 & 195,187 & 15,161 & 665 & 109,645 & 11,410 & 362 & 52,267 \\
\hline 1995 & 212,377 & 15,409 & 452 & 101,419 & 11,712 & 387 & 49,327 \\
\hline 1994 & 189,857 & 15,774 & 459 & 101,676 & 11,095 & 499 & 49,224 \\
\hline 1993 & 174,743 & 13,635 & 361 & 98,342 & 10,630 & 442 & 48,531 \\
\hline 1992 & 173,075 & 13,078 & 354 & 97,444 & 9,269 & 321 & 48,572 \\
\hline 1991 & 164,306 & 13,061 & 463 & 96,511 & 9,569 & 353 & 48,944 \\
\hline 1990 & 164,558 & 11,288 & 418 & 90,365 & 8,024 & 318 & 46,094 \\
\hline 1989 & 152,750 & 12,615 & 383 & 95,537 & 6,092 & 587 & 47,804 \\
\hline 1988 & 139,825 & 11,289 & 377 & 77,924 & 5,679 & 425 & 39,625 \\
\hline
\end{tabular}


Table 2

Background and Breadth of Database

\section{History of Database}

This database is the product of many years of effort. Originally this project was directed to parsing the IPO registration documents of just the semiconductor, biotechnology, and telecom equipment IPOs from 1996 through 2000. Based on the research value of these efforts (Kenney and Patton 2005, Patton and Kenney 2005), this work was expanded to include all de novo IPOs from June 1996 through 2000.

A second effort was mounted to build a database from 2001 through 2006 with support from the National Science Foundation - Geography and Regional Sciences (NSF 0647838). A third stage to collect this data for the years 1990 through 1996 was completed with funding from the Science of Science Policy program of the National Science Foundation (NSF 0915257).

Based on our work with Jay Ritter for the Kauffman Foundation on employment and revenue growth of firms following their IPO (Kenney, Patton, and Ritter 2012), we have also extended our database to include the time period from June 1996 through the year 2010. As part of our ongoing research on IPOs and new firm formation we have recently expanded this database to include the years 2011-2015. The database currently has data on 4,420 IPOs.

\section{Completeness}

This guide deals with the data about the firm going public and the offering itself, and is a complete database of emerging growth, de novo firms going public on American exchanges from 1990 through $2015^{2}$. The format of this database is Excel.

\section{Broad Definition}

Our definition of emerging growth companies differs from the definition used in the 2012 Jumpstart Our Business Startups (JOBS) Act. This bill defines emerging growth companies to be any company with annual revenue of less than $\$ 1$ billion. Our definition of emerging growth companies is based on their status as de novo and is not based on their revenue at the time of their IPO. Therefore, our definition includes the IPOs of Google and Facebook, which are excluded under the definition in the JOBS Act. 
Table 3

Excluded Firms From Database

\section{Restricted Firms}

This database is comprised of all emerging growth initial public offerings (IPOs) on American stock exchanges and filed with the Securities and Exchange Commission (SEC) from January 1990 through December 2015. In assembling the set of firms to be included we relied on Thomson Financial Venture Expert, SDC data, IPOScoop.com, and other sources to generate a list of all IPOs over this time period. From this list the following types of firms and filings were excluded: mutual funds, real estate investment trusts (REITs), asset acquisition or blank check companies, foreign F-1 filers, firms that had gone public at an earlier time, and all spin-offs and other firms that were not true de novo, emerging growth firms.

\section{Data Reviewed to Determine if Restricted}

Every firm going public must file a prospectus with the U.S. Securities and Exchange Commission prior to its initial public stock offering. The IPO is a defining event in the history of any firm, and it performs two functions. First, it provides the firm with capital so that it can continue its expansion. Second, after the IPO, the stakes of both management and investors, (subject to certain lock-up delays) becomes liquid. In return, the firm must conform to the reporting and transparency requirements imposed by the SEC under the Securities Act of 1933. One of the primary objectives of the Securities Act of 1933 is to require companies making a public offering of their securities to publicly disclose relevant business and financial information about their company so that potential investors can make an informed investment decision regarding the offering. To achieve this end the 1933 Act requires companies going public to file disclosure documents with the Securities and Exchange Commission, the most important of which are the general form S-1 registration statement and the 424B prospectus.

This database has been constructed directly from these registration statements and prospectuses. These documents were found on the SEC's Electronic Data, Gathering and Retrieval (EDGAR) website. Up until the advent of the SEC's EDGAR system, IPO registration statements and other SEC documents were filed in paper form in officially designated locations and libraries. Beginning in the 1980s the SEC began to provide Internet access to these documents through its EDGAR program, but it wasn't until June 1996 that public firms were required to file all of their documents in this format. Therefore, a complete EDGAR record of all IPO documents for firms going public only begins in June 1996.

For IPOs prior to June 1996 we have relied on IPO registration statements and prospectuses that were originally found in paper form. These documents were found at the Stanford Graduate School of Business Library in either pdf or TIFF format. It is from these documents that the data for IPOs from January 1990 through May 1996 were obtained. 
Table 4

Variable Sources

\section{Sources of Variables}

This database contains variables that pertain to the firm going public and the offering itself. Each firm is assigned a Central Index Key by the SEC which we are using as the firm's unique identifier. All of the variables in this database are extracted from each firm's prospectus (form 424B) or the firm's registration statement (form S-1).

\section{Main Variables Sources from SEC filings}

Company ID: The firm's Central Index Key (CIK) assigned by the SEC. This is used as the unique identifier of each firm in this database. If a firm was no longer publicly traded by the time EDGAR was initiated, it would not have a CIK. In these cases, we assigned a unique ID to the firm.

Company Name: Firm name at the time of the IPO.

IPO Year: The year of the IPO.

State of Incorporation: State of incorporation at the time of the IPO.

Company Street 1, Company Street 2,

Company City, The company's business address.

Company State,

Company Zip:

Stock Symbol: The stock market symbol, or ticker, of the firm's stock.

\section{Other Variables}

SEC SIC: This is the 4 digit Standard Industrial Code (SIC) assigned to the firm by the SEC'S Division of Corporate Finance.

Primary SIC: This is the 4 digit SIC found in the firm's S- 1 registration statement. This is the SIC the firm going public assigns to itself, and on occasion it does not agree with the SEC SIC.

Year Founded: This is the year the firm was founded. 


\section{Table 5}

\section{Random Selection Process}

\begin{tabular}{|c|}
\hline Random Selection Process for Selecting Firms in a Year \\
\hline $\begin{array}{l}\text { Step } 1 \\
\text { Start with a list of the firms from database for that year in alphabetical order. }\end{array}$ \\
\hline Count the number of firms. \\
\hline $\begin{array}{l}\text { Step } 3 \\
\text { If the number of firms is } 25 \text { or less, put all the firms in the sample. }\end{array}$ \\
\hline $\begin{array}{l}\text { Step } 4 \\
\text { Determine if the number of firms can be divided by a number that results in a number } \\
\text { between } 25 \text { and } 29 \text { (plus a possible remainder). For example, if there would be } 77 \text { in the } \\
\text { sample, you could divide by } 3 \text { and get an answer of } 25 \text {, remainder } 2 \text {. }\end{array}$ \\
\hline $\begin{array}{l}\text { Step } 5 \\
\text { If so, randomly select every nth firm in the list starting from the bottom. In the example of } \\
77, \text { you would start at the bottom and pick every } 3^{\text {rd }} \text { firm. }\end{array}$ \\
\hline $\begin{array}{l}\text { Step } 6 \\
\text { If not, if one dividing by one number produces too few and one number produces too many, } \\
\text { Divide by the number that produces too and randomly select the remaining firms from the } \\
\text { bottom of list. }\end{array}$ \\
\hline
\end{tabular}


Table 6

General Results

Percentage of firms in the different classes

\begin{tabular}{|c|c|c|c|c|c|}
\hline Year & Tech-maker & $\begin{array}{l}\text { Performance } \\
\text { Entrepreneurship }\end{array}$ & Kirznerian & Tech-enabled & $\begin{array}{l}\text { Performance } \\
\text { Entrepreneurship } \\
\text { \& Tech-enabled }\end{array}$ \\
\hline 1995 & $14.8 \%$ & $85.2 \%$ & $0.0 \%$ & $40.7 \%$ & $37.0 \%$ \\
\hline 1996 & $17.9 \%$ & $82.1 \%$ & $0.0 \%$ & $53.6 \%$ & $53.6 \%$ \\
\hline 1997 & $11.1 \%$ & $88.9 \%$ & $0.0 \%$ & $37.0 \%$ & $25.9 \%$ \\
\hline 1998 & $16.0 \%$ & $84.0 \%$ & $0.0 \%$ & $44.0 \%$ & $44.0 \%$ \\
\hline 1999 & $0.0 \%$ & $92.6 \%$ & $7.4 \%$ & $92.6 \%$ & $92.6 \%$ \\
\hline 2000 & $7.7 \%$ & $92.3 \%$ & $7.7 \%$ & $80.8 \%$ & $76.9 \%$ \\
\hline 2001 & $6.7 \%$ & $93.3 \%$ & $3.3 \%$ & $40.0 \%$ & $36.7 \%$ \\
\hline 2002 & $8.0 \%$ & $92.0 \%$ & $4.0 \%$ & $36.0 \%$ & $32.0 \%$ \\
\hline 2003 & $7.7 \%$ & $92.3 \%$ & $0.0 \%$ & $30.8 \%$ & $30.8 \%$ \\
\hline 2004 & $23.1 \%$ & $76.9 \%$ & $0.0 \%$ & $57.7 \%$ & $42.3 \%$ \\
\hline 2005 & $18.5 \%$ & $81.5 \%$ & $3.7 \%$ & $11.1 \%$ & $7.4 \%$ \\
\hline 2006 & $7.7 \%$ & $88.5 \%$ & $3.8 \%$ & $23.1 \%$ & $23.1 \%$ \\
\hline 2007 & $32.0 \%$ & $68.0 \%$ & $0.0 \%$ & $64.0 \%$ & $52.0 \%$ \\
\hline 2008 & $40.0 \%$ & $60.0 \%$ & $0.0 \%$ & $40.0 \%$ & $20.0 \%$ \\
\hline 2009 & $7.1 \%$ & $92.9 \%$ & $0.0 \%$ & $71.4 \%$ & $57.1 \%$ \\
\hline 2010 & $12.0 \%$ & $88.0 \%$ & $0.0 \%$ & $60.0 \%$ & $56.0 \%$ \\
\hline 2011 & $8.6 \%$ & $85.7 \%$ & $5.7 \%$ & $51.4 \%$ & $45.7 \%$ \\
\hline 2012 & $17.9 \%$ & $82.1 \%$ & $0.0 \%$ & $64.3 \%$ & $53.6 \%$ \\
\hline 2013 & $28.6 \%$ & $71.4 \%$ & $0.0 \%$ & $0.0 \%$ & $28.6 \%$ \\
\hline 2014 & $20.0 \%$ & $80.0 \%$ & $0.0 \%$ & $56.0 \%$ & $48.0 \%$ \\
\hline 2015 & $29.3 \%$ & $65.5 \%$ & $5.2 \%$ & $46.6 \%$ & $31.0 \%$ \\
\hline Avg. & $15.9 \%$ & $83.0 \%$ & $1.9 \%$ & $49.5 \%$ & $42.6 \%$ \\
\hline
\end{tabular}


Table 7

Prevalence of Tech-Maker Confidence Level

\begin{tabular}{|cc|}
\hline & Tech-maker \\
is & 91 \\
total sample & 568 \\
proportion is & $16.0 \%$ \\
conf level & 0.99 \\
proportion not & $84.0 \%$ \\
critical value & 2.576 \\
margin of & \\
error & 0.039643726 \\
lower limit & $12.1 \%$ \\
upper limit & $20.0 \%$ \\
\hline
\end{tabular}


Table 8

Comparison of Tech-maker and Performance Entrepreneurship

\begin{tabular}{|lrr|}
\hline & & \\
& & \\
& & \\
& Tech-maker & Performance \\
& & Entrepreneurship \\
& 91 & 469 \\
& 568 & 568 \\
& $16.0 \%$ & $82.6 \%$ \\
alpha & & \\
p bar & 0.492957746 & \\
q bar & 0.507042254 & \\
z & 22.43239845 & \\
p value & 0.000000 & \\
\hline
\end{tabular}


Table 9

Comparison of Kirznerian and Performance Entrepreneurship

\begin{tabular}{|c|c|c|}
\hline & $\begin{array}{l}\text { Performance } \\
\text { Entrepreneurship }\end{array}$ & Kirznerian \\
\hline & 469 & 13 \\
\hline & 568 & 568 \\
\hline & $82.6 \%$ & $2.3 \%$ \\
\hline alpha & 0.01 & \\
\hline p bar & 0.424295775 & \\
\hline q bar & 0.575704225 & \\
\hline z & 27.37421129 & \\
\hline$p$ value & 0.000000 & \\
\hline
\end{tabular}


Table 10

Comparison of Tech-maker and Tech-enabled/Performance Entrepreneurship

\begin{tabular}{|c|c|c|}
\hline & $\begin{array}{l}\text { Performance } \\
\text { Entrepreneurship } \\
\text { \& Tech-enabled }\end{array}$ & Tech-maker \\
\hline & 240 & 91 \\
\hline & 568 & 568 \\
\hline & $42.3 \%$ & $16.0 \%$ \\
\hline alpha & 0.01 & \\
\hline $\mathrm{p}$ bar & 0.291373239 & \\
\hline q bar & 0.708626761 & \\
\hline z & 9.728894569 & \\
\hline$p$ value & 0.000000 & \\
\hline
\end{tabular}




\section{CURRICULUM VITA}

NAME: $\quad$ Charles Raymond Olsavsky

ADDRESS: $\quad 408$ Davies Ave.

Louisville, KY 40208

DOB:

Youngstown, OH - December 20, 1956

EDUCATION

\& TRAINING: $\quad$ B.E. (cum laude), Management Engineering

Youngstown State University

1975-79

J.D. (cum laude), Law

University of Akron

1983-87

M.B.A. (with High Distinction), Business Management

University of Michigan (Ann Arbor)

2010-12

Professional Certificate, Financial Engineering

Columbia University (NY)

2013-14

Ph.D., Entrepreneurship

University of Louisville

2015-19

AWARDS: $\quad$ Tau Beta Pi

Law Review

AV Martindale-Hubbell rating

PROFESSIONAL SOCIETIES: Academy of Management

Florida Bar

INVITED PRESENTATIONS: The Entrepreneurship and Free Enterprise Research Conference, April 14, 2018, Lexington KY, University of Kentucky 